The Dickson Poon School of Law

SomersetHouse EastWing

Strand, London, WC2R 2LS

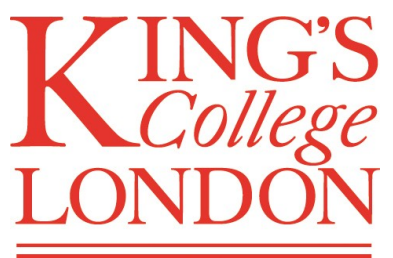

\title{
Transnational Constitutional Law
}

\section{Peer Zumbansen \& Kinnari Bhatt}

King's College London Dickson Poon School of Law

Legal Studies Research Paper Series: Paper No. 2018-05 

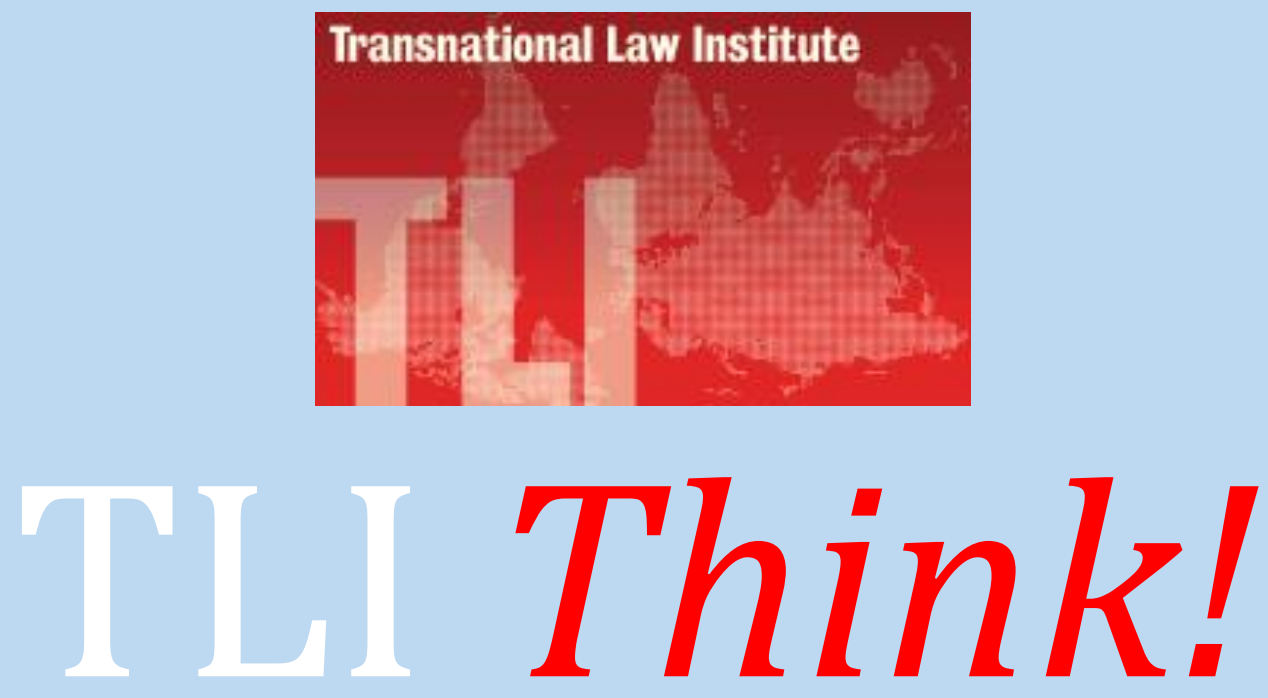

\title{
A Dickson Poon Transnational Law Institute, King's College London Research Paper Series
}

\section{Transnational Constitutional Law}

\author{
Peer Zumbansen and Kinnari Bhatt
}

\section{TLI Think! Paper 6/2018}

Editor: Peer Zumbansen, Director TLI / Managing Editor: Dayan Farias Picon

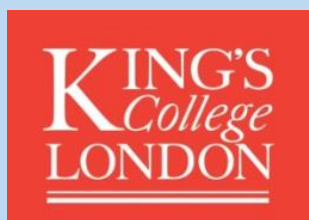

The Dickson Poon School of Law, King's College London

W: http://www.kcl.ac.uk/law/tli E: tli@kcl.ac.uk

This paper can be downloaded without charge at https://ssrn.com/abstract=3117352 


\begin{abstract}
This chapter provides an overview of the emerging field of transnational constitutional law (TCL). Whilst questions of constitutional law are typically discussed in the context of a specific domestic legal setting, a salient premise of TCL is to view constitutional law and its values by placing them 'in context' with existing and evolving cultural norms and political, social and economic discourses and struggles. Drawing on socio-legal investigations into the relationships between law and non-law and the significance of legal pluralism, TCL considers what role constitutional law and its values might play in shaping and bringing about social and legal transformation within an emerging global economic order in which non-territorially confined spaces of struggle involve transnational actors and social formation dynamics.

TCL thus emerges out of constitutional law in a transnational legal context. Based on Zumbansen's concept of Transnational Law (TL) as a methodological framework to study the Actors, Norms and Processes of legal formations in a global context, rather than positing TL as a distinct legal field, we examine transnational constitutional law phenomena in their social, political and economic contexts. This allows us to revisit and reassess well-known constitutional law concepts such as the rule of law, equality and access to justice in a new light, in particular where we confront - in this paper - legacies of these concepts in both the Global North and South. This engagement renders visible lived experiences of constitutional law and constitutionalism in local and transnational contexts, drawing attention to the growing number of those who have, through processes of globalisation, fallen out of, or were never made party to, the Western 'social contract'.

We present TCL as emerging on two levels. On a macro level, studies of comparative constitutional law and post-colonial approaches to law shine light on processes of globalisation and financialization as they manifest themselves in conflictual dynamics within trade law, and international human rights law, with regard to civil, socio-economic and cultural rights. TCL also emerges on a micro level through careful ethnographic and anthropological studies that examine different forms of what Saskia Sassen persuasively coined "Expulsions", meaning struggles and resistance against different forms of expropriation, eviction or alienation, within volatile economic and political landscapes.

Finally, our transnational critique of the 'rule of law' reflects our hope for a 'thick' and historically reflective RoL concept. In contrast to an idealised rendering of a pret-à-porter, universal rule of law, we argue for the continued need to explore transnational constitutional methodologies which are sufficiently differentiated to capture the manifold manifestations of constitutional conflicts, locally and spatially. The here presented case study applies this TCL approach to the struggle for indigenous identity, land rights and consultation.
\end{abstract}

Keywords: Transnational Constitutional Law; Constitutionalism; Global Constitutional Law; Rule of Law; Transnational Law; Actors, Norms, Processes; Land rights; Legal Pluralism; Development.

\author{
Institutional affiliation: \\ Peer Zumbansen \\ Professor of Transnational Law \\ Director, Transnational Law Institute \\ The Dickson Poon School of Law \\ King's College London \\ Strand WC2R 2LS London \\ United Kingdom \\ Email: peer.zumbansen@kcl.ac.uk
}

\author{
Kinnari Bhatt \\ Visiting Scholar \\ Transnational Law Institute \\ The Dickson Poon School of Law \\ King's College London \\ Strand WC2R 2LS London \\ United Kingdom \\ Email: kinnari@bhattsolicitor.info
}




\title{
Transnational Constitutional Law
}

\section{Peer Zumbansen \& Kinnari Bhatt}

\begin{abstract}
This chapter provides an overview of the emerging field of transnational constitutional law (TCL). Whilst questions of constitutional law are typically discussed in the context of a specific domestic legal setting, a salient premise of TCL is to view constitutional law and its values by placing them 'in context' with existing and evolving cultural norms and political, social and economic discourses and struggles. Drawing on socio-legal investigations into the relationships between law and non-law and the significance of legal pluralism, TCL considers what role constitutional law and its values might play in shaping and bringing about social and legal transformation within an emerging global economic order in which non-territorially confined spaces of struggle involve transnational actors and social formation dynamics.
\end{abstract}

TCL thus emerges out of constitutional law in a transnational legal context. Based on Zumbansen's concept of Transnational Law (TL) as a methodological framework to study the Actors, Norms and Processes of legal formations in a global context, rather than positing TL as a distinct legal field, we examine transnational constitutional law phenomena in their social, political and economic contexts. This allows us to revisit and reassess well-known constitutional law concepts such as the rule of law, equality and access to justice in a new light, in particular where we confront - in this paper - legacies of these concepts in both the Global North and South. This engagement renders visible lived experiences of constitutional law and constitutionalism in local and transnational contexts, drawing attention to the growing number of those who have, through processes of globalisation, fallen out of, or were never made party to, the Western 'social contract'.

We present TCL as emerging on two levels. On a macro level, studies of comparative constitutional law and post-colonial approaches to law shine light on processes of globalisation and financialization as they manifest themselves in conflictual dynamics

\footnotetext{
* Peer Zumbansen received his legal education at the Goethe University in Frankfurt, at the Université de Paris Ouest, and at Harvard Law School. He has been teaching in the areas of company, comparative private law, legal theory and transnational law. After holding a Canada Research Chair at Osgoode Hall Law School in Toronto for ten years, he was appointed the inaugural Professor of Transnational at The Dickson Poon School of Law and has been the founding Director of the Transnational Law Institute since 2014. Dr. Kinnari Bhatt is a Visiting Fellow at the Transnational Law Institute, King's College London, The Dickson Poon School of Law and an English qualified solicitor (LLB Law with French (Birmingham), M.Sc., PhD) experienced in the project financing and legal and regulatory reform of natural resource projects. She worked at White and Case LLP and Milbank Tweed, Hadley \& McCloy LLP and has served as legal advisor to the Ministry of Mineral Resources in Sierra Leone in a World Bank/DFID funded mining environmental, health and social regulatory drafting project and as civil society advisor on the Guinean Mining Code. Her research interests lie in transnational and comparative law, financing, human rights, land rights and legal/regulatory reform. The authors can be reached at kinnari@bhattsolicitor.info and peer.zumbansen@kcl.ac.uk.
} 
within trade law, and international human rights law, with regard to civil, socio-economic and cultural rights. TCL also emerges on a micro level through careful ethnographic and anthropological studies that examine different forms of what Saskia Sassen persuasively coined "Expulsions", meaning struggles and resistance against different forms of expropriation, eviction or alienation, within volatile economic and political landscapes.

Finally, our transnational critique of the 'rule of law' reflects our hope for a 'thick' and historically reflective RoL concept. In contrast to an idealised rendering of a pret-àporter, universal rule of law, we argue for the continued need to explore transnational constitutional methodologies which are sufficiently differentiated to capture the manifold manifestations of constitutional conflicts, locally and spatially. The here presented case study applies this TCL approach to the struggle for indigenous identity, land rights and consultation.

\section{A. Locating Constitutional Law in Times of Change}

Constitutional law is neither unitary nor is it universal. Constitutional values may - or, may not - align with or even express existing and evolving cultural norms. The relationship between constitutional law and legal culture can be both productive and destructive. ${ }^{1}$ Meanwhile, the relationship is a precious and precarious one, with legal certainty hanging in the balance, and with tender sensibilities towards what is done in the name of (constitutional) "law" by those subjected to it. ${ }^{2}$ A further challenge arises from the fact that constitutional law's instability is not merely a substantive, doctrinal or normative one, but always an institutional, a procedural one as well. Indeed, thinkers on the right and on the left have raised the question, 'Who is the guardian of the Constitution?'3 At its heart, this question not only points to a structure that allows to take

\footnotetext{
${ }^{1}$ Robert C. Post, Law and Cultural Conflict, 78 Chicago-Kent Law Review (2003), 485-508, at: 488-9: "With respect to law, we must theorize legal institutions as performing at least two functions in addition to that of enforcing ambient cultural norms. First, law is frequently used by government as a tool of social engineering to accomplish political desirably purposes. This is a routine use of law in the modern administrative state. [...] Second, law is sometimes used to revise and reshape culture. [...] When Catharine MacKinnon advocated legislation to suppress pornography, for example, her ambition was to use law to sever the link between female subordination and sexuality that she regarded as pervasive in American culture."

${ }^{2}$ Shiv Visvanathan \& Chandrika Parmar, Life, life world, and life chances: vulnerability and survival in Indian Constitutional Law, in: Boaventura de Sousa Santos \& César Rodríguez-Garavito (eds.), Law and Globalization From Below: Towards a Cosmopolitan Legality (Cambridge: Cambridge University Press, 2001), 339.

${ }^{3}$ Carl Schmitt, Politische Theologie (Berlin: Duncker \& Humblot, 1932). For an intriguing comparison between American and post-WWII German constitutionalism, see Gerhard Casper, Guardians of the Constitution, 53 Southern California Law Review (1980), 773-785. See also the account regarding the Constitutional Court in Colombia by Katrin Merhof, Building a bridge between reality and the constitution: The establishment and development of the Colombian Constitutional Court, 13:3 I.CON International Journal of Constitutional Law (2015), 714-732, and, regarding Eastern Europe after the Cold War: Kim Lane Scheppele, Guardians of the Constitution: Constitutional Court Presidents and the Struggle for the Rule of Law in Post-Soviet Europe, 154 University of Pennsylvania Law Review (2006), 1757-1851.
} 
a claim 'upwards' and to trigger a decision that binds all lower instances; it also is borne out of the fundamental belief in a normative, not merely institutional hierarchy. ${ }^{4}$ This distinction is important, it does not render visible the tension between what can also be an authoritarian legitimation and enforcement chain, on the one hand, and the always more precarious and vulnerable acceptance of a normative order and of the values it stands for, on the other.

Within constitutional law, strictly speaking, such queries used to be confined to a specified, legally constituted realm. With the civil revolutions in the US and France of the $18^{\text {th }}$ century, the nation-state would become the primary space in which constitutional orders would be created. In turn, the correlation between the political space created and governed by the constitution evoked that space's inside and outside. Constitutional lawyers would assess their country's own local legal history, while being only too aware of a need to have a comparative perspective on the law in other places, including those left behind or revolutionally changed. ${ }^{5}$ As such, it comes naturally to focus on one's own, on 'our' constitution and to do so out of an understanding, that constitutional values are created, implemented, fought for and fought over in a local context - from Philadelphia to Paris, Berlin to Pretoria, Delhi to London, Karachi to Manila. ${ }^{6}$

Meanwhile, given a constitutional order's tenuous relation to the socio-economic, political and cultural context out of and in exchange with which it is created and must live, it seems obvious that, if anything, a field such as 'constitutional law' would have to be equipped with a particularly receptive sensorium. In other words, constitutional law should be particularly 'open' to signals from the different orders in which the constitutional legal order is struggling for recognition and acceptance. ${ }^{7}$

\footnotetext{
4 Dinah Shelton, Normative Hierarchy in International Law, 100:2 American Journal of International Law (2006), 291-323, at: 291: "Systems of law usually establish a hierarchy of norms based on the particular source from which the norms derive. In national legal systems, it is commonplace for the fundamental values of society to be given constitutional status and afforded precedence in the event of a conflict with norms enacted by legislation or adopted by administrative regulation (...)."

5 András Sájo \& Michel Rosenfeld, Introduction, in: A.Sájo \& M.Rosenfeld (eds.), Oxford Handbook of Comparative Constitutional Law (Oxford: Oxford University Press 2012), 1-22, at: 3: "Comparative constitutional inquiry became particularly relevant in the aftermath of the revolutions in the United States and France. The Founding Fathers and the French revolutionaries had to invent a new organization of the state and they could rely only to a limited extent on pre-existing structures. The empirical evidence offered by comparison was both a source of inspiration and of legitimation." But see Rosalind Dixon \& Tom Ginsbury, Introduction, in: R.Dixon \& T.Ginsburg (eds.), Comparative Constitutional Law (Cheltenham: Edward Elgar 2011), 1-15, highlighting, id., at 2-3, the late arrival of public and constitutional law comparison, in contrast to the earlier efforts among private lawyers to study similarities and differences between legal systems.

${ }^{6}$ Meanwhile, often enough locally focused efforts at constitutional change are conducted in awareness of similar struggles elsewhere: Benjamin Gregg, The Human Rights State. Justice Within and Beyond Sovereign Nations (Philadelphia: University of Pennsylvania Press 2016); Kathryn Sikkink, The Justice Cascade: How Human Rights Prosecutions Are Changing World Politics (New York: Norton \& Norton 2011).

${ }^{7}$ See the encouraging proposal by Ran Hirschl to take into view the socio-economic and cultural factors that shape constitutional legal cultures: R.H., From comparative constitutional law to comparative constitutional studies, 11:1 I.CON International Journal of Constitutional Law (2013), 1-12.
} 
But not only is the constitution's place "in" a society one that constantly shifts between contention and contestation, restraint and empowerment, but the constitution also gives rise to and operates within a space that transcends a country's territorial but also jurisdictional order. "[C]onstitutions neither originate nor operate in a vacuum. Their import cannot be meaningfully described or explained independent of the social, political, and economic forces, domestic and international, that shape a given constitutional system." 8 The here surfacing implications of seeing constitutional law 'in context', as part of complex layers of legal culture, ${ }^{9}$ cannot be overstated. Drawing, then, on the one hand, on socio-legal studies, which include legal anthropological and legal-sociological investigations into the relationship between law and non-law and the phenomena and significance of legal pluralism ${ }^{10}$, while, on the other, pushing these inquiries into the evolving, non-territorially confined, but 'spatialised' regimes of norm-creation, ${ }^{11}$ contextualised constitutional law studies 2.0, as it were, are today, irreversibly, caught up in complex, interdisciplinary but also politically charged discourses. As scholars, for example, in the global south, highlight particular features of Latin American, Indian or South African constitutional orders with regard to the increased attention paid to socioeconomic inequality, ${ }^{12}$ we are prompted to recognize how such assertions align with and complement an important and growing body of post-colonial studies, ${ }^{13}$ race and inequality studies ${ }^{14}$ and, within legal scholarship itself, the so-called Third World Approaches to International Law. ${ }^{15}$ Such cross-connections crucially complement the emerging interest among comparative constitutional law scholars in the (both domestic and international) political economy of their field. ${ }^{16}$ As Ran Hirschl noted, "[o]ften

${ }^{8}$ Hirschl, above note 4 , at 2 .

9 David Nelken, Using the Concept of Legal Culture, 29 Australian Journal of Legal Philosophy (2004), 1-26, and Naomi Mezey, Law as Culture, 13 Yale Journal of Law \& the Humanities (2001), 35-67. And see, with a particular emphasis on religious norms: Dieter Grimm, Conflicts between General Laws and Religious Norms, 30 Cardozo Law Review (2009), 2369-2382; Michael A. Helfand, Religious Law in the $21^{\text {st }}$ Century, 41 Pepperdine Law Review (2014), 991-996, and Ricardo René Larémont, Islamic Law, Muslim-Christian Relations, and the Transition to Democracy in Nigeria's Fourth Republic, 1:1 Journal of the Middle East and Africa (2010), 25-42.

${ }^{10}$ Gunther Teubner, Global Bukowina: Legal Pluralism in the World Society, in: G.Teubner ed., Global Law Without a State (Dartmouth 1997), 3-28; Peer Zumbansen, Transnational Legal Pluralism, 1:2 Transnational Legal Theory (2010), 141-189.

${ }^{11}$ Saskia Sassen, When Territory Deborders Territoriality, 1:1 Territory, Politics, Governance (2013), 21-45; Philip Liste, Geographical knowledge at work: Human rights litigation and transnational territoriality, 22:1 European Journal of International Relations (2016), 217-239.

12 David Bilchitz, Constitutionalism, the Global South, and Economic Justice, in: Daniel Bonilla Maldonado (ed.), Constitutionalism of the Global South (Cambridge: Cambridge 2013), 51-52: “...in contrast to the constitutions of France, the United States, and Canada (...) the three constitutional systems [explored in the book - South Africa, India, Latin America] "share a core normative commitment towards state institutions having obligations to address the economic injustices and inequalities in their societies."

${ }^{13}$ Alpana Roy, Postcolonial Theory and Law: A Critical Introduction, 29 Adelaide Law Review (2008), 315357.

14 Tanya Katerí Hernández, Comparative Judging of Civil Rights: A Transnational Critical Race Theory Approach, 63 Louisiana Law Review (2003), 875-886.

15 Makau Mutua, What is TWAIL?, 94 ASIL American Society of International Law Proceedings (2000), 3138; James T. Gathii, TWAIL: A Brief History of Its Origins, Its Decentralized Network, and a Tentative Bibliography, 3:1 Trade, Law and Development (2011), 26-64.

16 Hirschl, above note 4, at 1-2: "In this new constitutional environment, even bastions of insular parochialism cannot entirely avoid developments taking place internationally." 
excluded from the canonical discourse are other crucial questions, such as the real-life impact of constitutional jurisprudence and its efficacy in planting the seeds of social change; how constitutions reflect and shape nation-hood and identity; how constitutions construct, not merely constrain, politics (e.g., by framing the goals and interests people believe they can pursue in politics); the actors and factors involved in demanding or bringing about constitutional transformation; the place of constitutionalism, national and trans-national, in the emerging global economic order; or the ever-increasing judicialization of politics worldwide and its impact on the legitimacy of the courts and the quality of democratic governance more generally." 17

Drawing 'lessons' from these developments for constitutional law and constitutional legal studies in a global context will continue to be a project for years to come. As a result, any engagement with the current and evolving state of what a group of forward looking scholars coined as "comparative constitutionalism"18 much be both an inward- and outward looking exercise. With constitutional "law" being interwoven in local legal and political cultures, any constitutional analysis must remain focused on the concrete, locally and historically evolving context, if it is to produce insights into the idiosyncrasy of a specific culture. At the same time, legal cultures are both territorial and non-territorial spatial regimes and, as such, respond to a myriad of factors that shape their direction, contents and dynamics. While it seems, in this light, almost impossible to mark the inner and outer limits of constitutional law, therein lies the promise of a transnational analysis of constitutional law and constitutionalism. By investigating the evolving phenomena, manifestations and arguments of constitutional legal ordering from a legal pluralist perspective, it becomes possible to combine a close scrutiny of local context with a wideangle view of the ways in which norms migrate in and out of a particular regime, and what the drivers of such migrations are.

In light of the foregoing, a contextual approach to the discussion of a so-called 'transnational' perspective on constitutional law should appear like a logical conclusion.

What we propose in this chapter is an approach to law that applies respected constitutional norms and values in global settings. By placing comparably well-known and settled concepts in a less clearly illuminated setting and landscape, we hope to gain fresh insights into both the 'familiar' and the extraordinary and provoke bold crossdisciplinary debates. Constitutional rights like the rule of law (RoL), fairness and access to justice present an opportunity to bridge and draw lines between competing and asymmetric spheres of societal power. Through these principles we might forge links between familiar liberal demarcations: 'positive' and 'negative' roles of states, 'negative'

\footnotetext{
${ }^{17}$ Hirschl, above note 4 , at 3.

${ }^{18}$ Norman Dorsen, Michel Rosenfeld, Andras Sajo \& Susanne Baer, Comparative Constitutionalism (2 ${ }^{\text {nd }}$ ed., 2010).
} 
rights against the state versus 'positive' rights towards the state. ${ }^{19} \mathrm{~A}$ TCL approach might also foster and support new forms of representation and political voice, ${ }^{20}$ providing an exciting opportunity to speak to power.

\section{Constitutional Law's Permanent State of Crisis, Challenge and Renewal}

At times of political upheaval, economic and social insecurity, both rich and poor, privileged and disenfranchised, become attuned to a growing feeling of general volatility, instability and unpredictability. ${ }^{21}$ While each will likely experience the 'present' from distinct vantage points and with markedly different types and levels of exposure to uncertainty and risk, there is a strong and widely shared awareness that things are not well. ${ }^{22}$ But, how widely shared and homogenous is that sentiment? In this current state, one may well argue (and, perhaps, even think) that everyone seems to be in the same boat. But, if that were true, how do we explain the deep divides that became apparent in Myanmar, Turkey, Trump's America or the UK's gambled-away EU membership?23

Some of the ensuing questions must concern competence and responsibility. In other words, who can explain the fragmentation of polities, the growing attractiveness, seemingly, of populist rhetoric and politics, ${ }^{24}$ and, moreover, the consequences for democratic cultures following from the growing gap between the privileged and the disenfranchised? In a climate, which is so distinctly marked by a sense of loss of orientation, direction and confidence, is one to turn to 'experts' and analysis, to faith and religion, or to activism, resistance and collaboration? And, in relation to each, is everyone able to choose freely between such options? What alliances should one seek to form or to join, which epistemic communities can one trust? With the walls breaking down between 'privileged' knowledge, produced by professional 'knowledge workers' such as academics, think tank inhabitants or, occasionally, political leaders, and the knowledge of the man or woman 'on the street', where do competences lie? Where does and should a future-oriented deliberation take place? What are the parameters, constraints and opportunities for a locally embedded and globally connected and networked civil society,

\footnotetext{
${ }^{19}$ See, for example, David P. Currie, Positive and Negative Constitutional Rights, 53 Chicago Law Review 864890 (1986); Günter Frankenberg, Why Care? The Trouble with Social Rights, 17 Cardozo Law Review 13651390 1997).

20 Domingo A. Lovera-Parmo, The Right to Social Protest: Negotiating Constitutional Meanings, PhD Dissertation, Osgoode Hall Law School, York University, 2016, on file with P. Zumbansen. Ibid., at 8: "Social Protests [...] are direct and popular forms of interpreting constitutions. Through protests - although certainly not only by their means - the people (or the peoples) directly take over the struggle to define constitutional contours."

21 Pankaj Mishra, Age of Anger (2016).

22 Tony Judt, Ill Fares the Land (2010).

${ }^{23}$ Arlie Russell Hochschild, Strangers in their own land. Anger and Mourning on the American Right (2016); Danny Dorling, Inequality and the 1\% (2014); Lisa McKenzie, Getting By. Estates, Class and Culture in Austerity Britain (2015).

24 Jan Werner Müller, What is Populism? (2016); Cas Mudde \& Cristóbal Rovira Kaltwasser, A Very Short History of Populism (2017).
} 
and what is the relationship between the formats in which we speak to each other, near and far, and the regulatory framework that governs these exchanges?

Constitutional law (CL) is an unlikely candidate to be directly called upon for an emergency briefing on the current state of socio-economic inequality and voters' disenchantment with the way things are. Instead, CL and, along with it, the larger edifice and architecture, both institutionally 'real' and imaginary symbolic, of law and of the 'rule of law', of a body of norms associated with 'public' (rather than 'private') law, that is, a body of norms dignified to govern, guide and, at times, even inspire societies' fates, seems quite removed from our daily lives. Who, today, turns their hopes to CL as a refuge and saviour, which thrones above and impregnates society, however dysfunctional, and hostile present living conditions might be? CL's place is, thus, an ambiguous one. While it is a core component of a democratic state's legal foundation of legitimacy, its lived experience comes down to how successfully it can be relied upon, consciously or merely habitually (my letters arrive, and they are unopened). But, the question is whether CL and, with it, our understanding of law's constitutive and, simultaneously discerning and governing role is still sufficiently conceptualised to keep up with the ways of life of people, worldwide. No one writes 'letters' any longer, and the protectedness of the ways in which almost all communication takes places today, might be an entirely different situation. We 'speak' to each other more frequently and for greater lengths of time, online than face-toface. We navigate websites, 'do research' when we have a question and buy, read, watch, interact and find satisfaction online, rather than turn to the person next to us. Meanwhile, our communication is channelled, sped up or slowed down, ${ }^{25}$ redirected, monitored, listened-to, copied, saved or reproduced with us both 'knowing' and 'not knowing'. ${ }^{26}$ In the background of this digital babble (and, Panopticon ${ }^{27}$ ) lies the law. Law governs the internet, at least in part, ${ }^{28}$ and the ways in which our comprehensively onlined lives now unfold, rely on the law's active involvement. ${ }^{29} \mathrm{New}$ spaces of human interaction, brought

25 Tim Wu, Network Neutrality, Broadband Discrimination, 2 Journal of Telecommunications and High Technology Law (2003), 141-175, originally published on SSRN - in fact, one of the most-often downloaded articles on the Social Science Research Network (www.ssrn.com) of all times.

26 Cole Stryker, Hacking the Future. Privacy, Identity, and Anoymity on the Web (2012); David Lyon, Surveillance after Snowden (2015); Michael Geist (ed.), Law, Privacy and Surveillance in Canada in the PostSnowden Era (2015).

27 Jeremy Bentham, Panopticon: or The Inspection House: Containing the IDEA OF A NEW PRINCIPLE OF CONSTRUCTION, applicable to Any Sort of Establishment, in which persons of any description are to be kept under inspection, and in particular Penitentiary Houses (...), written in the year 1787, from Crecheff in White Russia. To a Friend in England, by Jeremy Bentham, of Lincoln's Inn, Esquire, in: Jeremy Bentham, The Panopticon Writings (Miran Bozovic ed., London: Verso 1995), 29-95. This was, of course, rendered particularly influential by Michel Foucault, in ibid., Surveiller et Punir (Paris: Gallimard 1975). See also Shoshana Zuboff, Big other: surveillance capitalism and the prospects of an information civilization, 30 Journal of Information Technology (2015), 75-89, and Thomas McMullan, What does the panopticon mean in the age of digital surveillance?, The Guardian, 23 July 2015.

${ }^{28}$ Jack Goldsmith \& Tim Wu, Who Controls the Internet? Illusions of a Borderless World (Oxford: Oxford University Press 2006).

${ }^{29}$ Andras Sajó \& Clare Ryan, Judicial reasoning and new technologies. Framing, newness, fundamental rights and the internet, in: Oreste Pollicino \& Graziella Romano (eds.), The Internet and Constitutional Law: The protection of fundamental rights and constitutional adjudication in Europe (Aldershot: Routledge 2016), 325. 
about by political change or technological innovation, prompt law's adaptation and often enough a fundamental, if time-pressing reassessment of the adequateness of existing concepts and instruments. ${ }^{30}$ Mostly, we experience the law's touch as light, as merely enabling or as opening doors. Beyond the implicit assumption that we have more or less exhausted the legal dimension of our existence in the internet by paying a monthly flat rate to a 'provider', law is likely to come under consideration only on the occasion of a crisis, of a break-down of the relations entered into online, or in the case of criminalised misbehaviour. In our daily, practically constant, and mostly uninterrupted use of the opportunities offered by the Net, we are drawn to think of law as mere background setter for the largely autonomous universe of self-determined, global interaction, allegedly free from any restrictions. Law is (probably) there only to provide a guarantee in the case that one of our many digital interactions (well, purchases) fail. Otherwise, we might acknowledge at times that it exercises a varying degree of ethical control over 'digital content', protects minors and others, but is generally as invisible as the kitchen or maids' change room in a large hotel.

What, then, are reliable references, 'safe havens' or anchor points that could serve as orientation markers for living under the 'rule of law'? A striking feature of our times in which law has become such a seemingly tradeable and malleable entity for those who found themselves swept into positions of (legal!) power on the stroppy seas of populist discontent, ${ }^{31}$ is that, at the same time, it is also being invoked with ever more intensity and fervour as a resource for democratic revival, social and economic emancipation and sustainable, peaceful development. ${ }^{32}$ The next question must then be, it seems, what is meant by 'law' and how can this search for and the belief in the possibility (and, necessity) of law's response to this general sense of volatility be located within the existing frameworks of legal culture? Such questions pose themselves with imminent urgency in

\footnotetext{
30 Mark Tushnet, Internet Exceptionalism: An Overview from General Constitutional Law, 56 William \& Mary Law Review (2015), 1637-1672, at 1640: "Considering the use of sound amplifying equipment by trucks cruising city streets to disseminate a political message, Justice Robert Jackson wrote, "The moving picture screen, the radio, the newspaper, the handbill, the sound truck and the street corner orator have differing natures, values, abuses and dangers. Each, in my view, is a law unto itself." [Kovacs v Cooper, 336 U.S. 77, 98 (1949) (Jackson J., concurring)] To that, we can now add the Internet."

${ }^{31}$ Anthony D. Romero, Donald Trump: A one-man constitutional crisis, ACLU American Civil Liberties Union, 13 July 2016, online. European Parliament, Report on the situation of fundamental rights: standards and practices in Hungary (A7-0229/2013), Rapporteur: Rui Tavares, online; see also the interview by the Green European Journal of Kim Lane Scheppele \& Rui Tavares, The Rule of Law Challenge in Europe: From Hungary to Poland, 23 January 2016, online.

32 See Mattias Kumm, Taking "the dark side" seriously: Constitutionalism and the question of constitutional progress, 13:4 I.CON International Journal of Constitutional Law (2015), 777-785, at 779: "In most actual circumstances where constitutionalism is in crisis people are not just facing economic and cultural adjustment problems. They have good reasons to be concerned and have a plausible intuitive grasp that the system is skewed against them. And constitutional practices often play a central role in loading the dice, legitimating and entrenching structural pathologies."
} 
times of crisis, which unfold in contexts of transformation, transition and deep discontent. ${ }^{33}$

\section{Enter Transnational Constitutional Law}

The foregoing observations point to the degree to which constitutional conflicts have become spatialized. While struggles over socio-economic, political, religious and cultural rights manifest themselves locally, they reverberate and resonate across jurisdictional borders. Both the original conflicts and the locally evolving legal responses get 'picked up' elsewhere, explicitly or implicitly incorporated into the policy discourse, the activist and political rhetoric, and the emerging legal-doctrinal vocabulary in related constitutional struggles in other places. The horizontal "migration" of constitutional ideas $^{34}$ thus goes beyond the realm of comparative public law in that the transnational engagement among public institutions and private actors, civil society members, lawyers, judges and activists, gives rise to an increasingly dense space of constitutional normativity. What makes this space so particular and worthy of closer inspection is its constitutive, creative and open-ended character. We are interested in taking stock of both "settled" constitutional norms and doctrine ${ }^{35}$ and emerging, aspirational, contentious and conflictual 'law in struggle'. In our understanding, this emerging space of transnational constitutionalism is hard and soft at the same time, as it is constituted by migrated, transplanted and incorporated doctrine, on the one hand, while being the space of lived and experienced struggle over rights-expression and rights-formation in myriad forms. The underlying idea here is one of a transnational space of legal pluralism, in which the co-existence of 'official' and 'in-official' law, of law and non-law, is produced through a toand-fro between assertion and contestation of constitutional values across a constantly re-arranging constellation of actors, norms and processes. ${ }^{36}$ This space is both larger and thicker' than that captured by either comparative public or private law. It is constituted by the continued struggle over the meaning and content of law in the face of diversity, inequality and complexity. ${ }^{37}$ In this light, Transnational Constitutional Law (TCL) emerges as a methodological perspective on law that engages constitutional law and constitutionalism 'in action' in global contexts.

\footnotetext{
33 See, for example, the observations by D.M. Davis, Constitutional borrowing: The influence of legal culture and local history in the reconstitution of comparative influence: The South African Experience, 1:2 I.CON International Journal of Constitutional Law (2003), 181-195.

34 Sujith Choudhry, The Migration of Constitutional Ideas (2002)

35 For a discussion of how transnational norms "settle" in local contexts, see the ground-breaking work by Gregory Shaffer and Terence Halliday, Transnational Legal Orders, in: Peer Zumbansen (ed.), Oxford Handbook of Transnational Law (forthcoming, 2018).

36 Peer Zumbansen, Manifestations and Arguments: The Everyday Operation of Transnational Legal Pluralism, in: Paul Schiff Berman (ed.), Oxford Handbook of Global Legal Pluralism (forthcoming, 2019)

37 This manifests itself in areas as seemingly diverse as feminist legal theory and climate change governance. See, for example, Joanne Conaghan, Intersectionality and the Feminist Project in Law, in: Davina Cooper (ed.), Intersectionality and beyond: law, power and the politics of location (2009), and Elizabeth Fisher, Eloise Scotford \& Emily Barritt, The Legally Disruptive Nature of Climate Change, 80:2 Modern Law Review (2017), 173-201.
} 
This transnationalisation of law, which manifests itself in the increased interconnectivity of public and private norm-creating processes both within and beyond jurisdictionally marked legal spheres ${ }^{38}$ deserves particular attention from the perspective of constitutional law. Transnational law's displacement and contestation, arguably, of the dominant principles of (state-based) legal and political authority and the suggestion that concepts such as 'authority' 39 and 'sovereignty' 40 are bound to change as more and more private 'regulators' 41 move into the fold, places the continuing investigation into what is and what isn't 'transnational law' squarely within a constitutional law analysis. ${ }^{42}$ But, by reflecting, in turn, on constitutional law in a global context, both - constitutional and transnational law's - legal, anthropological and socio-legal constitutive elements come into view in sharper relief. ${ }^{43}$ In this light, the earlier argued for need to understand transnational law from a methodological perspective would sensibly apply to constitutional law as well. ${ }^{44}$ As far as constitutional law itself is concerned, its pronounced level of recognition and authority provides an even greater incentive to engage with it in the context of the described transnational regulatory landscape.

\section{Normativity in Transnational Constitutional Law}

The foregoing should have made it somewhat clear that we are dealing with transnational constitutional law from a socio-legal perspective. So, rather than focusing on the here alluded-to shifts from public, state-based governmental regulation to private and publicprivate, hybrid forms of regulatory governance ${ }^{45}$ from the perspective of doctrine and legal principle, the starting point is a sociological and political economy account of the degree to which this shift has been actually occurring in reality. This requires lawyers in both public and private law to place foundational principles of their fields in relation to what continues to be an interdisciplinary analysis of norm generation and norm contestation under dramatically transformed conditions. ${ }^{46}$ By highlighting the constantly

38 See Liste, note 11 above.

${ }^{39}$ Roger Cotterrell \& Maksymilian Del Mar (eds.), Authority in Transnational Legal Theory (2016).

40 Seyla Benhabib, The Future of Democratic Sovereignty and Transnational Law, European University Institute, Max Weber Programme (MWP) Lecture 04/2012 (online).

${ }^{41}$ See, for example, Tim Büthe \& Walter Mattli, The New Global Rulers: The Privatization of Regulation in the World Economy (2011); Gralf-Peter Calliess \& Peer Zumbansen, Rough Consensus and Running Code: A Theory of Transnational Private Law (2010).

42 Roger Cotterrell, What is Transnational Law?, 37:2 Law \& Social Inquiry 500-524 (2012), at 501: "The new term is 'transnational law', widely evoked but rarely defined with much precision."

${ }^{43}$ Ralf Michaels, Law and Globalization - Beyond the State, in: Law and Social Theory (Reza Banakar \& Max Travers eds, $2^{\text {nd }}$ ed, 2013): "transnational Law does not seem very helpful: If transnational law encompasses all legal (and non-legal!) rules, it may be thought to lose any distinguishing potential. If everything is transnational law, nothing really is."

${ }^{44}$ Peer Zumbansen, Transnational Law, in: Encyclopaedia of Comparative Law (Jan Smits ed., $2^{\text {nd }}$ ed., 2012), 898-935; for a similarly oriented analysis of transnational rules with a focus on sources rather than content, see already Emmanuel Gaillard, Transnational Law: A Legal System or a Method of Decision Making?, 17:1 Arbitration International 59-71 (2001), 60-62.

45 Colin Scott, Fabrizio Cafaggi \& Linda Senden, The Conceptual and Constitutional Challenges of Transnational Private Regulation, 38:1 Journal of Law and Society (2011), 1-19.

46 Terence C. Halliday \& Pavel Osinsky, Globalization of Law, Annual Review of Sociology (2006), 447-470 (online). 
evolving interactions of constitutionalism with developments in the relationship of law to society, socio-economic conditions, politics, culture and value, we seek to direct attention to the inherent embeddedness of constitutional law in a larger universe of law as a 'cultural process'. As such, TCL can be considered a useful method for planting familiar flags in places and contexts that are typically unfamiliar terrain to a constitutional lawyer, but where constitutional conflicts are ubiquitous. ${ }^{47}$

TCL offers valuable opportunities for us to turn our attention more directly on the building blocks and starting assumptions of 'our' law, and of our understandings of 'constitutionalism' against the background of what we identify as "public", as "private" and as lying outside of law. Through the lens of TCL, we develop a sensitivity for such introspective and comparative scrutiny in different contexts. As we engage in such efforts, TCL has the potential to shine light on the pre-existing historic biases in already well defined Western legal and political systems and structures of liberal constitutionalism, equality and rights. Under that light, what might become visible are the (un)constitutional, exclusionary effects of all-to-familiar, liberal narratives of 'progress'48, 'superior Western culture', 'territorial protection', 'development', 'security' 49 and even 'environmental protection'. ${ }^{50}$ The case study we are including below focuses on indigenous rights struggles and will illustrate the operation of these familiar liberal narratives in context.

A TCL approach to constitutionalism is distinguishable from 'constitutional law' and its traditional focus on limiting government. The fundamental legality of the process is one that is authorised by the people who are then reconstituted as subjects by the structures that constitutions put in place. ${ }^{51}$ This paradox of constituting/constituted is understood as the foundation of constitutional legitimacy, 52 generating rights and obligations. TCL seeks to shift the focus out of the "known" and settled to invite both local and comparative introspections of what is understood in different places as 'constitutional order' and constitutional 'law'. And, building on such a locally oriented approach to constitutional

\footnotetext{
${ }^{47}$ Some such conflicts have been approached through the doctrine of 'horizontal effect': see, for example, Aoife Nolan, Holding non-state actors to account for constitutional economic and social rights violations: Experiences and lessons from South Africa and Ireland, 12:1 I.Con International Journal of Constitutional Law (2014), 61-93; Hugh Collins, On the (In)compatibility of Human Rights Discourse and Private Law, LSE Law, Society and Economy Working Paper 7/2012.

48 Thomas Skouteris, The Notion of Progress in International Law Discourse (2009).

${ }^{49}$ Ramesh Thakur, Ethics, International Affairs and Western Double Standards, 3:3 Asia \& the Pacific Policy Studies (2016), 370-377.

${ }^{50}$ Ian Clark, Hegemony in International Society (2011), ch. 9; see also J.Timmons Roberts, Multipolarity and the new world (dis)order: US hegemonic decline and the fragmentation of the global climate regime, $21 \mathrm{Global}$ Environmental Change (2011), 776-784.

51 Uday S. Mehta, Indian Constitutionalism. crisis, unity and history, in: The Oxford Handbook of the Indian Constitution (Sujit Choudhry, Madhav Khosla \& Pratab Bhanu Mehta eds., Oxford University Press: Delhi, 2016), 38.

52 Jürgen Habermas, On the Internal relation between the Rule of Law and Democracy, in: Constitutionalism and Democracy (Richard Bellamy ed., 2006), 267-275, at 268, speaking of what looks like a "philosophical trick".
} 
law/constitutionalism in context, TCL refers not to a global constitutional legal order, but seeks to grasp - in a methodological, critical vein - the emergence of a discursive space in which constitutional normativity is contested, engaged with, promulgated and resisted. Such a space co-evolves with the actual development of specialised institutional and procedural norms, ${ }^{53}$ which continue to exist in fragmented, regulatory realms, but contribute to the thickening of the transnational constitutional space in a normative sense. ${ }^{54}$

In this respect, we remain sceptical towards assertions of 'global law'. Instead, we posit that there is a possibility to speak - cautiously - of a space, a discursive realm of normative tensions and dynamics, which both challenges and is challenged by sectoral norms and principles. This space is transnational not in the sense of constituting a globally recognised and universally accepted and, even less, world-wide enforceable legal order. ${ }^{55}$ It is transnational in that the normative tensions between competing and conflicting claims and interpretations as they emerge in different localities around the world increasingly resonate or collide with those surfacing elsewhere, thereby feeding a border-transgressing conflict out of which arises a thicker discourse of rights contestation and generation.

The dynamics at work within this space resemble what socio-legal scholars have, at different times, been unpacking as the tension between law 'on the books' and 'law in action'.56 The methodological approach here represented by TCL takes this tension seriously and sheds light on the concrete conflicts that arise out of confrontations between those able to rely on protected rights and those to whom access to justice is legally or factually denied. ${ }^{57}$ While access to justice [A2J] has long been a staple of critical lawyers' engagement with 'their' legal system in local and national settings, 58 we can observe a distinct transnationalization of A2J efforts in recent years. Responding, for

${ }^{53}$ T. Alexander Aleinikoff, Transnational Spaces: Norms and Legitimacy, 33 Yale Journal of International Law (2008), 479-490; Frank J. Garcia, Globalization's Law: Transnational, Global or Both?, Boston College Law School Faculty Paper 1/1/2016.

${ }^{54}$ For example, in the case of FPIC. See Fergus MacKay, Indigenous People's Right to Free, Prior and Informed Consent and the World Bank's Extractive Industries Review, Sustainable Development Law \& Policy (2004), 43-65. See also the case of gender rights: Vicki C. Jackson, Gender and Transnational Legal Discourse, 14:2 Yale Journal of Law \& Feminism (2002), 377-391, and Sally Merry Engle, Human Rights and Transnational Culture: Regulating Gender Violence through Global Law, 44:1 Osgoode Hall Law Journal (2006), 53-75.

55 In this sense also Ulrich Sieber, Legal Order in a Global World. The Development of a Fragmented System of National, International, and Private Norms, 14 Max Planck Yearbook of United Nations (2010), 1-49.

56 Roscoe Pound, Law in Books and Law in Action, 44 American Law Review (1910), 12-36; Jean-Louis Halperin, Law in Books and Law in Action: The Problem of Legal Change, 64 Maine Law Review (2011), 4576.

57 David Szablowski, Transnational Law and Local Struggles: Mining, Communities and the World Bank (2007); Asher Flynn \& Jacqueline Hodgson (eds.), Access to Justice and Legal Aid. Comparative Perspectives on Unmet Legal Need (2017).

58 Roderick A. MacDonald, Access to Justice and Law Reform, 10 Windsor Yearbook of Access to Justice (1990), 287-337; Surya Deva, Public Interest Litigation in India: A Critical Review, 28:1 Critical Justice Quarterly (2009), 19-40. 
example, to the spatial expansion of multi-tiered supply and value chains, legal scholars ${ }^{59}$ and activists ${ }^{60}$ have been drawing resources together in the hope of mobilizing and channelling resources of awareness building and legal response formation. A central characteristic of this development from a TCL perspective is the growing awareness among legal scholars of the manifold and intricate differences between legal conflicts, which could mistakenly be compared as "familiar" or "similar" and in response to which one could be tempted to resort to "established" doctrine and legal principles. ${ }^{61}$ It is then, from a TCL perspective, that the concept or idea of a transnational rule of law refers to a socio-legal investigation into the differently situated formal as well as informal actors, norms and processes that operate within and between local and transnational contexts. ${ }^{62}$

On the basis of the here proposed, contextual approach to an analysis of transnational constitutional law and constitutionalism, the focus is on concrete sites of norm contestation and norm generation. Through a comparative socio-legal lens, we search for reverberations of manifestations of resistance against structural forms of violence, which can be traced to border-crossing regimes of power. Typical examples involve dynamics of expropriation, ${ }^{63}$ border control and enforcement ${ }^{64}$ and human endangerment in the course of degraded infrastructures. ${ }^{65}$ The emerging understanding of the interconnectedness of relation remind us that what might seem a distant act of resistance against unlawful or illegitimate abuse of public or private power in the context, for example, of the killing of striking workers and activists at the South African Lonmin mine ${ }^{66}$ might share important characteristics with other local, struggles for labour and human rights, notwithstanding the geographical and contextual differences. To identify and to give legal expression to recurring instances of violence and social concern across legal jurisdictions is assisted by a powerful 'sociology of globalization'67, on the one hand, while prompting investigations into the normative potential of a critique of

59 Grietje Baars et al, The role of law in global value chains: a research manifesto, London Review of International Law (2015).

60 Amnesty International/Business \& Human Rights Resource Centre, Creating a paradigm shift: Legal solutions to improve access to remedy for corporate human rights abuse, 4 September 2017.

${ }^{61}$ Dana Raidgrodski, What Can Comparative Legal Studies Learn from Feminist Legal Theories in the Era of Globalization?, 43:3 University of Baltimore Law Review (2014), 349-393; Emma Partrignani, Otherness, Pluralism and Context - Underground issues in comparative legal studies, University of Lapland, Dissertation (2017).

62 See, in that regard, Peer Zumbansen, Defining the Space of Transnational Law: Legal Theory, Global Governance, and Legal Pluralism, 21:2 Transnational Law and Contemporary Problems (2012), 305-336.

63 Saskia Sassen, Expulsions. Brutality and Complexity in the Global Economy (2014).

${ }^{64}$ A remarkable critique is offered by Reece Jones, Violent Borders: Refugees and the Right to Move (2016). 65 Dina M. Siddiqi, Starving for Justice: Bangladeshi Garment Workers in a 'Post-Rana Plaza World', 87 International Labor and Working-Class History (2015), 165-173; Juliane Reinecke \& Jimmy Donaghey, After Rana Plaza: Building Coalitional Power for Labour Rights Between Unions and (Consumption-Based) Social Movement Organisations, 22:5 Organization (2015), 720-740.

66 See the account at the website of the Marikana Commission of Inquiry: http://www.marikanacomm.org.za/.

67 Saskia Sassen, A Sociology of Globalization (2007). 
interconnectedness, on the other. ${ }^{68}$ Exploring the spatial architecture of regulatory and epistemic regimes ${ }^{69}$ and comparing diverse modes of social 'expulsion'70 such as complex mining techniques and social dispossession from welfare systems, not as disconnected 'states of exception'71 but as a window into the major quotidian, new-normal dynamics of local-global life in which experiences of expulsion, alienation and exclusion are shared amongst diverse factual contexts. ${ }^{72}$ In comparison to, and possibly complementing and grounding some of the currently debated approaches to emergencies of 'global' constitutional law, ${ }^{73}$ a further elaboration of a contextual methodology of TCL depends on this empirical evidence.

With the methodological pursuit of TCL starting from ground-up sites of social struggle, "well-known" and "established" core institutions of the (Western) rule of law tradition the legality principle, equal treatment and access to justice ${ }^{74}$ - at best provide a rough guide to the comparative lawyer's investigation into the local constitutional order's operation on the ground. The challenge is to put in relation local manifestations of struggles over recognition and representation, voice and inclusion, access and participation. ${ }^{75}$ This relationing requires a distinction of layers but also the recognition of the movements between them. On what we might call a 'macro' level, conflicts occur over constitutional protections and principles of justice in matters of trade and investment treaties, ${ }^{76}$ or within the intensifying and thickening practice of international human rights adjudication with regard to civil, socio-economic, cultural and religious

${ }^{68}$ See also Iris Marion Young, Responsibility and Global Labor Justice, 12:4 Journal of Political Philosophy (2004), 365-388, and Doreen Massey, Geographies of responsibility, 86:1 Geografiska Annaler: Series B: Human Geography (2004), 5-18.

${ }^{69}$ Saskia Sassen, The Embeddedness of Electronic Markets: The Case of Global Capital Markets, in: The Sociology of Financial Markets 17 (Cetina/Preda, eds., 2005); David Harvey, The Sociological and Geographical Imaginations, International Journal of Politics, Culture and Society 211 (2005).

70 Saskia Sassen, Expulsions: Brutality and Complexity in the Global Economy (Harvard University Press 2014).

71 See, in that vein, Giorgio Agamben, State of Exception (2012).

72 Mark Blythe, Austerity. The History of a Dangerous Idea (2013); Lisa McKenzie, Getting By: Estates, Class and Culture in Austerity Britain (2015); Tom Gillespie, Accumulation by urban dispossession: struggles over urban space in Accra, Ghana, 41:1 Transactions of the Institute of British Geographers (2015), 66-77; Davina Cooper, Everyday Utopias. The Conceptual Life of Promising Spaces $(2014$.

${ }^{73}$ See, for example, the insightful analysis by Cheryl Saunders, Towards A Global Constitutional Gene Pool, 4:3 National Taiwan University Law Review (2009), 1-38.

74 Compare the "four universal principles" identified by the World Justice Project: www.worldjusticeproject.org/about-us/overview/what-rule-law, namely 1. Accountability, 2. Just Laws, 3. Open Government, and 4. Accessible \& Impartial Dispute Resolution.

75 Esther Hernandez-Medina, Social Inclusion through Participation: The Case of the Participatory Budget in Sao Paulo, 34:3 International Journal of Urban and Regional Research (2010), 512-532; Dmytro Khutkyy, Participatory budgeting: an empowering democratic institution, Open Democracy, 6 November 2017.

76 Frank Garcia, Global Justice and International Economic Law. Three Takes (Cambridge: Cambridge University Press, 2013), at 13: "The significance of globalization lies in its transformation and extension of [...] social interactions and social processes beyond national boundaries. When we speak of global justice we are arguing, in effect, that globalization is creating social outcomes and processes of the sort that make justice relevant at the global level and that we need to consider whether these outcomes and processes are indeed acceptable in terms of core principles." 
rights. ${ }^{77}$ Simultaneously, on a 'micro' level, we see through sharper lenses and sustained ethnographic work, how constitutionalisation processes evolve in the context of ongoing engagements and struggles with the changing political economic climate. Thus, through 'grounded' context specific examples like displacement and global supply chains, TCL provides a methodological tool for making visible the 'new normal' global interconnectivity of people, movements, communities, their unique histories and their engagements in locally unfolding and globally reverberating social and political struggles.

\section{The Building Blocks of Transnational Constitutional Law}

The foregoing suggests a considerable legal theoretical debt, incurred by a concept such as TCL. In this section, we will try to identify some of these in succession. First, the notion of a contextual dimension of (constitutional) law is not new. The so-called Legal Realists, writing in the early twentieth century, repeatedly pointed to the power asymmetries between allegedly equal social actors, to highlight the constitutional dimension of what traditional doctrine represented as 'private law'. ${ }^{78}$ This attention to a public and constitutional law dimension of private law relations continues to be an important cornerstone of the here proposed concept of TCL.

Second, TCL is greatly influenced by the theoretical approach extended in third world approaches to international law. This approach provides a critical confrontation with the 'external' effects of constitutional law in the history of the global expansion of Western law $^{79}$. It contributes to more exchanges between international lawyers who have been calling attention to the colonial origins, and legacies, of their field ${ }^{80}$ and constitutional lawyers engaged in testing the boundaries of and the interactions between local, regional and global constitutionalism. ${ }^{81} \mathrm{~A}$ crucial dimension of such engagement is the linkage between work done in the so-called 'Global North' and 'Global South' 82 , as the following section explores.

77 Katharine G. Young, Constituting Economic and Social Rights (2012); Paul O'Connell, Vindicating SocioEconomic Rights. International Standards and Comparative Experiences (2012). See also Mark Gibney \& Wouter Vandenhole (eds.), Litigating Transnational Human Rights Obligations: Alternative Judgments (2014).

${ }^{78}$ Morris R. Cohen, The Basis of Contract, 46:4 Harvard Law Review 553-592 (1933); Robert Hale, Coercion and Distribution in a Supposedly Non-Coercive State, 38:3 Political Science Quarterly 470-494 (1923).

${ }^{79}$ Antony Anghie, Imperialism, Sovereignty and the Making of International Law (Cambridge: Cambridge University Press, 2004).

80 James T. Gathii, TWAIL: A Brief History of Its Origins, its Decentralized Network, and a Tentative Bibliography, 3:1 Trade, Law \& Development 26-64.

81 See Anne Peters, The Merits of Global Constitutionalism, 16:2 Indiana Journal of Global Legal Studies 397411, and - with a focus on regional trends of constitutional law in Latin America, Armin von Bogdandy, Ius Constitutionale Commune en América Latina - Beobachtungen zu einem transformatorischen Ansatz demokratischer Verfassungsstaatlichkeit, 75:2 Heidelberg Journal of International Law (Zeitschrift für ausländisches öffentliches Recht und Völkerrecht) 345-382 (2015).

82 See, for example, the work done by Diego Lòpez Medina, Teoría impure del derecho (Bogotá et al, LEGIS, 2004), for the elaboration of a critique of what he calls 'transnational legal theory' (Teoría Transnacional del Derecho - TTD), and his identification of 'sites of production' and 'sites of reception' (sitios de producción y sitios de recepción), which has been extremely influential and widely cited and engaged with 
There has been a growth of studies identifying 'migration' of constitutional ideas ${ }^{83}$ and issues of normative pluralism. These processes typically take place when international judicial dialogue engage across borders and with less formalised constitutional norms, practices and beliefs. ${ }^{84}$ Through a body of comparative constitutional studies, we trace an evolution of constitutional law within and beyond diverse cultural, ethnic or religious communities, regulatory areas, legal fields per se and jurisdictional boundaries. For example, critical constitutionalism discourse from Latin America reveal the blind spots of teoría tansnacional del derecho ('TTD ${ }^{85}$ '). In applying a set of North American and Western European constitutional law principles against and in comparison, to which developments in other parts of the world can be measured, the TTD represents no more than what Medina depicted as an 'abstract discourse of global scope'. In other works, Bernal explores the meaning of Western concepts like the constitutional replacement doctrine $^{86}$ and transitional justice in the framework of the Colombian permanent constitution. ${ }^{87}$

Third, TCL is shaped through studies concerning the implementation of socio-economic rights or access to 'common goods' like land and water in local and global contexts. Such studies frequently consider RoL and access to justice issues. Collaborative North-South scholarship has resulted in exciting Latin-American and Western studies on socioeconomic rights. ${ }^{88}$ Others deliver analysis on the role played by local constitutional courts

in Latin America. See, with a focus on the debates among scholars predominantly in the 'North', the important and horizon-expanding observations by Seyla Benhabib, The Future of Democracy and Transnational Law, Max Weber Lecture 2012, European University Institute, Florence 2012. See also Benhabib's collaboration with Kwame Appiah, the late Iris Marion Young and Nancy Fraser, Justice, Governance, Cosmopolitanism, and the Politics of Difference. Reconfigurations in a Transnational World. Distinguished W.E.B. Du Bois Lectures 2004/2005, Berlin (Humboldt University) 2007.

83 See Sujit Choudhry (ed.) The Migration of Constitutional Ideas (Cambridge, 2006), and Philip Liste, Transnational Human Rights Litigation and Territorialised Knowledge: Kiobel and the 'Politics of Space', 5.1 Transnational Legal Theory 1-19 (2014), Philip Liste \& Antje Wiener, Lost Without Translation? CrossReferencing and a New Global Community of Courts, 21:1 Indiana Journal of Global Legal Studies 263-296 (2014).

${ }^{84}$ Norman Dorsen, Michel Rosenfeld, Andras Sajo \& Susanne Baer, Comparative Constitutionalism (2 ${ }^{\text {nd }}$ ed., 2010).

85 See Diego Lòpez Medina, note 15.

86 See Carlos Bernal, Unconstitutional constitutional amendments in the case study of Colombia: An analysis of the justification and meaning of the constitutional replacement doctrine, 11 ICon International Journal of Constitutional Law 339 (2013).

${ }^{87}$ Carlos Bernal, Transitional Justice within the Framework of a Permanent Constitution: The Case Study of the Legal Framework for Peace in Colombia, Cambridge Journal of International and Comparative Law (3)4: 1136-1163(2014)

${ }^{88}$ See the contributions to the important collection of essays resulting from a collaboration among scholars in Colombia and the United States: Helena Alviar García/Karl Klare/Lucy A. Williams (ed.^eds.), SociAL AND EConomic Rights in Theory and Practice. Critical Inquiries (2015). See also two recent, well-informed overviews of theory developments in Latin America from Germany, one from the director at the Max Planck Institute in Heidelberg (Armin von Bogdandy, Ius Constitutionale Commune en América Latina Beobachtungen zu einem transformatorischen Ansatz demokratischer Verfassungsstaatlichkeit, 75 HEIDELBERG JOURNAL OF INTERNATIONAL LAW (HJIL) 345 (2015), and one from a young legal scholar at the Viadrina University in Frankfurt (Oder): Heiner Fechner, Neue Rechtstheorie(n) in Lateinamerika. Vom Alternativen Recht zum Emanzipatorischen Rechtspluralismus, 48 KRITISCHE JUSTIZ 446 (2015). 
and tribunals in enforcing rights to water. ${ }^{89}$ In the context of social rights and health care Ferraz $^{90}$ critically examines the jurisprudence of the Brazilian courts surrounding constitutional rights to health and its effect on the poorest. O'Connell's ${ }^{91}$ work observes a marked trend among 'apex courts' such as in Canada, India and South Africa, each with important, yet varying histories of pronounced elaboration of socio-economic rights, towards the adoption of neo-liberal, 'market-friendly' rights interpretations. His macro level study demonstrates how constitutional law principles such as equality and access to justice seriously necessitates a modern transnational approach to law which must include the full range of human rights and not just those negative civil and political rights typically favoured by Western states. Other socio-economic legal studies on displacement, housing rights and human rights in the United States, India and South Africa ${ }^{92}$ evidence how the main principles underlying questions of land and displacement of communities is consistently based on neoliberal Lockean principles of how to derive the greatest value from a piece of land. Spatio-legal methodologies provide socioeconomic insights into the development of original forms of property right to further the RoL, substantive equality and advance constitutional fairness for historically marginalised aboriginal groups ${ }^{93}$ in Canada.

Works on economic and social justice also contribute to the emergence of TCL. The echoes of what the political economist, C.B Macpherson calls "economic justice" 94 specifically captures the tensions between a legal culture resting on rights and an economic system which has grown autonomous from political or legal control. ${ }^{95}$ Economic struggles can today be heard in struggles over the accountability and responsibility for labour and

${ }^{89}$ See, with regard to water, Carlos Bernal, The Right to Water: Constitutional Perspectives from the Global South, on file with P. Zumbansen.

${ }^{90}$ Ferraz, Harming the Poor Through Social Rights Litigation, Texas Law Review, Vol. 89:1643 (2011).

91 See Paul O'Connell, The Death of Socio-Economic Rights, 74:4 Modern Law Review 532-554 (2011) and in this vein also Kerry Rittich, The Future of Law and Development: Second Generation Reforms and the Incorporation of the Social, 26 Michigan Journal of International Law 199-243 (2004). Also, the insightful historical analysis by Christopher McCrudden, of the references to human dignity by national and international courts, from which - despite its ubiquitous use in case law and legislation - no overarching and universally coherent concept has emerged: Christopher McCrudden, Human Dignity and Judicial Interpretation of Human Rights, 19:4 European Journal of International Law 655-724 (2008).

92 Albia C, Scott B and Tissington K 'Demolishing Housing Rights in the Name of Market Fundamentalism: The Dynamics of Displacement in the US, India and South Africa', Chapter 4 in L Minkler, The State of Economic and Social Human Rights: A Global Overview (CUP 2013).

93 Blomley N, 'Making Space for Property' (2014) 104 Annals of the Association of American Geographers 129 contemplating a robust new form of legal property for the Nisga'a following historical research into the original treaty with the Crown which included a clause that the Nisga'a Aboriginal Title continues as modified. His study creates a new form of legal property in which the Canadian Nisga'a First Nation can possess an Aboriginal fee simple through fusing Westerns and traditional property systems:

${ }^{94}$ C.B Macpherson, The Rise and Fall of Economic Justice, in: ibid., The Rise and Fall of Economic Justice, and other Essays. The role of state, class and property in twentieth-century democracy (Oxford University Press: Toronto, 1987, 1-20, at 2.

95 Macpherson, above note 25, at 4: "The turning point is not the emergence of markets and merchants, much less of private property and slavery. It is the achievement by merchants and markets of a relative autonomy or independence from the state.[...] this required, for the first time in history, a concept of economic justice distinct from the general notion of justice." 
human rights abuses in global supply chains, ${ }^{96}$ in the resistance against an imposed austerity straight jacket across Europe ${ }^{97}$ or the fight of indigenous peoples in Peru, Colombia and Ecuador against FDI-related expropriation and displacement. ${ }^{98}$ What we find is a growing disconnect between globally spatialised ${ }^{99}$ and financialised markets, ${ }^{100}$ between a system of nation-states that continues to pivot 'markets' versus 'states'101 and between economic actions and social contexts, thus presenting new and unsolved challenges." 102

As we note from the above studies, the effects of global financialization can and frequently are felt locally. It is on the local level that conflicting views of inequality, socio-economic protection and distributive justice collide with internationally pervasive policies, ${ }^{103}$ and generate innovative approaches to rights advocacy and adjudication. ${ }^{104}$ We must ask questions regarding the future shape of local experiences with the RoL, the welfare state, with deregulation and privatization. We must also be mindful of how different 'our' accounts of those developments and their associated struggles are from those in other places. Building on the above bodies of literature, TCL provides the means for a focused enquiry into the 'constitutional' dimension of the local and transnational interplay of actors, norms and processes.

\footnotetext{
${ }^{96}$ Larry Catá Backer, Are Global Supply Chains Transnational Legal Orders? What We Can Learn from the Rana Factory Plaza Building Collapse, 1:1 UC Irvine Journal of International, Transnational, and Comparative Law 11-66 (2016).

97 Guy Standing, The Corruption of Capitalism (2016); Wolfgang Streeck, How Will Capitalism End? (Verso, 2016); Michelle Everson, Europe at the Crossroads, Critical Legal Thinking, 20 June 2016, available here: http://criticallegalthinking.com/author/michelle-everson/.

98 Luis Vittor, Indigenous People and Resistance to Mining Projects. Revista. Harvard Review of Latin America, Winter 2014, available at: https://revista.drclas.harvard.edu/book/indigenous-people-andresistance-mining-projects

${ }^{99}$ Saskia Sassen, The Embeddedness of Electronic Markets: The Case of Global Capital Markets, in: Karin Knorr \& Alex Preda (eds.), The Sociology of Financial Markets (Oxford: Oxford University Press, 2005), 17 37 , at 26-27.

100 Ronald Dore, Financialization of the Global Economy, 17:5 Industrial and Corporate Change 1097-1111 (2008); Peer Zumbansen \& Cynthia Williams, The Embedded Firm: Corporate Governance, Labour and Finance Capitalism, Comparative Research in Law \& Political Economy [CLPE] Research Paper 18/2011.

101 John G Ruggie, International Regimes, Transactions and Change: Embedded Liberalism in the Postwar Economic Order, 36:2 International Organization 379-415 (1982), 404ff.

102 Jürgen Kocka, Capitalism. A Short History (Princeton, NJ: Princeton University Press, 2016), at 114.

${ }^{103}$ See Paul Collier, The Bottom Billion (Oxford: Oxford University Press, 2007); Jeffrey Dunoff, The Political Geography of Distributive Justice, in: Chios Carmody, Frank J. Garcia \& John Linarelli (eds.), Global Justice and International Economic Law (Cambridge: Cambridge University Press, 2012), 153-184, 182-183, pointing to the limits of trade-focused forms of international intervention.

104 Sandra Liebenberg \& Katharine G. Young, Adjudicating social and economic rights. Can democratic experimentalism help? in: Helena Alviar García, Karl Klare \& Lucy A. Williams (eds.), Social and Economic Rights in Theory and Practice (London: Routledge, 2015), 237-257, at 241: "Not tethered by 'rights essentialism' and the need to formulate the fixed content of rights, courts make liability determinations in fluid interdependence with the initiation of the remedy."
} 


\section{B. Characteristics of Transnational Constitutional Law}

\section{Emergence of TCL within Contested Spaces}

Factual examples of TCL tend to emerge from spaces in which communities, peoples, private and public entities increasingly encounter one another because of global interconnectedness. A factual application site in this regard is the intensification in courts, public debates and even board rooms and shareholder meetings on the rights and treatment of marginalised people. Examples include the growing resistance against the granting of mining licenses for foreign multinationals and the frequent cases of expropriation and dramatic displacement of affected indigenous communities. ${ }^{105}$

A good example of community grounded resistance is found in the Oyu Tolgoi mining project concerning pastoralist herders displaced to make way for a copper and gold mine part financed through a consortium of public and private investors, including the Mongolian state. To draw attention to the social hardship and injustice caused by mining operations displaced community members with support of OT Watch (a national NGO) and Gobi Soil (a local NGO organised by displaced herders), submitted two complaints concerning the project to the Complaints Advisory Ombudsman of the International Finance Corporation. Complaints ${ }^{106}$ detailed how 89 herder households, reliant on traditional livestock systems like winter and summer camps lost access to grazing land and water sources vital to their indigenous nomadic livelihoods in terms of access to water and grazing land. In this case, the ability of herders to access these mechanisms resulted in the negotiation of comprehensive agreements between project developers and resettled herders in which significant concessions have been made concerning redesign of mine project to avoid sacred sites, enhanced consultation, compensation, an official letter of company apology for diversion of sacred water sources, re-establishment of water sources and creation of new ones to protect and keep customary livelihood practices. ${ }^{107}$ In this case at least, local communities have, through non-legally binding ombudsman complaints mechanisms successfully draw attention to their situation of land expulsion and injustice. ${ }^{108}$

\footnotetext{
105 Id., at 11-12. See also the United Nations' "Indigenous Peoples Indigenous Voices FaCt SheET”, 2009 (?), ENTITLED: INDIGENOUS PEOPLES AND INDUSTRIAL CORPORATIONS, available at: http://www.un.org/en/events/indigenousday/pdf/Indigenous_Industry_Eng.pdf. There, it says on p.2.: "Particularly serious challenges to indigenous rights are generated by mega-projects, such as mining, oil, gas and timber extraction, monoculture plantations and dams. The impact of such projects includes environmental damage to traditional lands in addition to loss of culture, traditional knowledge and livelihoods, often resulting in conflict and forced displacement, further marginalization, increased poverty and a decline in the health of indigenous peoples."

106 Oyu Tolgoi Complaint No. 2 dated 3 February 2013, page 2 <http://www.caoombudsman.org/cases/document-links/documents/UndaiRiverComplaint_Feb32013_ENG.pdf>

107 Herders' Complaint Resolution Agreement dated 9th May 2017, between Khanbogd Soum Government, Elected Representatives of Khanbogd Soum Bagh Herders and Oyu Tolgoi LLC< http://www.caoombudsman.org/cases/document-links/documents/OT2 ComplaintResolutionAgreement2 ENG.pdf.

${ }_{108}$ However, it is worth noting that the agreements do not address the most important issue of securing herders' land tenure.
} 
This type of mechanism is a unique type of 'micro' project specific ombudsman complaints mechanisms developed by financial investors. Comprised of a plural public/private form of legal authority functioned with drawing attention to the hardship caused by private sector development and policy in areas such as land resettlement. ${ }^{109}$ Under these mechanisms, affected communities can lodge direct complaints with project developments which are then independently scrutinised. The aim is to address issues of public accountability and transparency to communities and the public concerning project activities and private policies. ${ }^{110}$ Arguably these mechanisms provide communities with a mouthpiece through which they can directly speak to and communicate their grievances to powerful entities with which they have no formal legal relationship, and they provide an interesting tool through which TCL methodologies can be applied to other suitable local struggles.

The Mongolian case echoes similar processes in India where courts have entertained numerous letters, telegrams, and even postcards directly from the poor, children or disabled treating them as formal writ petitions and thus dispensing with formal, timely and expensive legal processes for vulnerable groups. ${ }^{111}$ Colombian citizens benefit from a progressive legal 'tutela' system protecting equality and fundamental rights enshrined in the country's constitution. Established under the 1991 constitution, tutela provides for the immediate protection of fundamental rights threatened by a public authority. The procedure for invoking a tutela is simple: an individual may complain, there is no need for a lawyer and in some cases, a complaint may even be verbal. Once submitted a judge is legally obliged to respond. It has therefore become a popular method for Colombian citizens to claim their constitutional rights particularly in a country where poverty would otherwise limit access to justice. ${ }^{112}$

The three examples demonstrate new processes of social inclusion evolving from the bottom up which in some cases have developed into constitutional law making. As the examples demonstrate, the tangible local impacts of global markets are clear. We know that "human rights abuses associated with the exploration and exploitation of nonrenewable resources include, among others, violation of the right to life, forced displacement and destruction of the environment on which indigenous peoples

\footnotetext{
109 I Brownlie GS Goodwin-Gill \& S Talmon, The Reality of International Law: Essays in Honour of Ian Brownlie (Clarendon 1999) 336.

${ }^{110}$ See Alfredsson G and Ring R, The Inspection Panel of the World Bank: a different complaints procedure (Raoul Wallenberg Institute human rights library, Martinus Nijoff Publishers 2000).

${ }^{111}$ For example, see Rama Murthy $v$ State of Karnataka (1997) 2 SCC 642 in which a letter written to the supreme court by a prisoner from the central jail about denial of rightful wages, non-eatable food and physical and mental torture was registered as a writ petition and Upendra Baxi (Dr) v. State of U.P. [(1983) 2 SCC 308], the Supreme Court's attention was drawn to the abject condition prevailing in protective homes and based on a letter written by two law professors issued remedial guidelines.

112 Delaney P, Legislating for Equality in Colombia: Constitutional Jurisprudence, Tutelas and Social Reform, The Equal Rights Review (2008) Vol 1, 50, online at http://www.equalrightstrust.org/ertdocumentbank/Legislating\%20colombia.pdf.
} 
depend."113 Foreign investments or 'land grabbing' on traditional lands is an area of much scholarship. Potentially irreconcilable tensions arise in which the state as shareholder and public law duty bearer is forced to act in entirely conflicting ways regarding the same territory and peoples." 114 The changing role of the state means that state regulation is no longer the sole author and monitor of legal rules. New dilemmas arise. For example, to whom and through what mechanisms, might indigenous groups assert rights to be consulted on developments affecting their traditional land? The latter consultation point is examined in the case study.

New global contexts for exploring constitutional law also force us to critically re-think the legality of existing 'liberal' rights, like the indigenous rights regime and its assumptions discussed in the case study, as it now rapidly cross borders and roams into new geographies. New forms of human rights advocacy and community building projects like those discussed above are fast emerging and at the same time, more require creation. These are just some ways in which real-world developments significantly shape the new contexts in which TCL might come to play a crucial role.

\section{The Rule of Law and Fundamental Rights}

The common thread weaving through TCL is the understanding of globalisation and financialization processes through a RoL perspective. The concept of the RoL is a wellknown legal, political and even economic concept. ${ }^{115}$ It is not necessary to provide a detailed account of its history, meaning 116 and challenges ${ }^{117}$ here. What we will provide is an overview of the 'ingredients' that comprise a TCL approach to the RoL.

First, our conceptualisation of the RoL questions how and for whom it is established. TCL might question the value system caught up, endorsed and given validity to in Western

\footnotetext{
113 Julian Burger, Indigenous Peoples, Extractive Industries and Human Rights, report for the European Parliament's Subcommittee on Human Rights, Strasbourg, 2014, available at: http://www.europarl.europa.eu/RegData/etudes/STUD/2014/534980/EXPO STU\%282014\%29534980 EN.pdf, at 5.

${ }^{114}$ See The Double Life of International Law: Indigenous Peoples and Extractive Industries (Developments in the Law), 129 Harvard Law Review (2016), 1755, online at: http://harvardlawreview.org/2016/04/thedouble-life-of-international-law-indigenous-peoples-and-extractive-industries/ (conclusion).

115 See Edward Palmer Thompson, Whigs and Hunters. The Origins of the Black Act (1975), and Alvaro Santos, The World Bank's Uses of the 'Rule of Law' Promise in Economic Development, in: THE NEW LAW AND EConomic DeVElopment. A Critical ApPraisal 253 (Trubek/Santos, eds., 2006).

${ }^{116}$ For a very helpful and insightful guide to competing interventions, see CHRISTOPHER MAY, THE RULE OF Law. The Common Sense of Global Politics (2014), ch. 2 ("Defining the rule of law, between thick and thin conceptions"), id., at 33-56.

117 Katharina Pistor/Antara Haldar/Amrit Amirapu, Social norms, rule of law, and gender reality. An essaay on the limits of the dominant rule of law paradigm, in: GLOBAL PERSPECTIVES ON THE RULE OF LAW 241 (Heckman/Nelson/Cabatingan, eds., 2010), who address the RoL's shortcomings in capturing and theorizing levels of inequality, using women as but one example; see also the critique of the World Justice Project's 'Rule of Law' index, in which private actors engage in the public work of measuring rule of law: Jothie Rajah, 'Rule of Law' as Transnational Legal Order, in: TransnATIONAL LEGAL ORDERS 340 (Halliday/Shaffer, eds., 2015).
} 
constitutions. In this manner, it continues and builds upon third world approaches to law that supports a reading of international law within a historical and socio-economic context as undertaken by E. P. Thompson's analysis of the ominous 'Black Act' in light of the RoL as an unqualified human good.118

Second, a transnational constitutional law approach to the RoL is inherently 'plural'. We know that the RoL is inherently a construction of Western constitutional law. The notion of 'legal pluralism' introduced by Sally Engle Merry provides a crucial theoretical intervention to the embedded assumptions of Western legal thought. Her short article called for inclusion of virtually every society as legally plural regardless of a colonial past. ${ }^{119}$ Looking at the RoL through a legal pluralist lens reveals a complex and constantly shifting and evolving assemblage of actors, norms and processes. Instead of a neatly constituted and institutionalized system of, say, 'checks and balances',120 'constitutional democracy',121 and the legality principle ${ }^{122}$ a legal pluralist RoL presents us with a methodological challenge. A truly pluralist perspective on the RoL must seek to decentre the material infrastructure of the state, its institutions and processes and expose the hidden assumptions embedded within liberalism and its laws.

Attempts to 'provincialise' 123 Western narratives of the RoL and a 'global' constitutional law ${ }^{124}$ lead into unknown territory and even charges of neo-colonialism. Once we let our gaze wander in the search of references to and analyses of the RoL in the 'Global South', we embark on a journey that is experimental and developing. Studies from India critically reassess the Western influence on shaping 'comparative' constitutional law. Assessments question the assumption within comparative constitutional law that a community's conceptions of law, politics, and justice could be enriched by studying foreign experiences. ${ }^{125}$ Similarly, Baxi's assessment of South Asian Constitutionalism prepares the ground for a call for "a new postcolonial nomenclature". That nomenclature must be informed by a fundamental recognition of the colonial heritages that influence constitution-making and understanding that there is 'more' to governance than entailed

118 EdWARd Palmer Thompson, Whigs And Hunters. The Origins OF THE Black ACt (1975).

${ }^{119}$ Sally Engle Merry, Legal Pluralism, 22 LAW \& SocieTy REVIEW 869 (1988), 869.

120 Compare Federalist PAPER No.51, "The Structure of the Government Must Furnish the Proper and Balances Between the Different Departments", http://avalon.law.yale.edu/18th century/fed51.asp.

121 Michel Rosenfeld, The Rule of Law and the Legitimacy of Constitutional Democracy, 74 Southern California Law Review 1307 (2001), 1308.

${ }^{122}$ Compare the RoL definition as offered by the World Justice Project, which posits, inter alia, that: "The government and its officials and agents as well as individuals and private entities are accountable under the law." See http://worldjusticeproject.org/what-rule-law.

${ }^{123}$ Compare Dipesh Chakrabarty, Provincializing Europe. Postcolonial Thought and Historical DifFerence, 2nd ed. [orig. 2000] (2007).

124 Antje Wiener, Global Constitutionalism: Mapping an Emerging Field. Background paper for the Conference: Constitutionalism in a New Key?, Berlin 28-29 January 2011 (http://cosmopolis.wzb.eu/content/program/conkey_Wiener_Mapping-Field.pdf) (2011).

125 Sujit Choudhry, How to Do Comparative Constitutional Law in India: Naz Foundation, Same Sex Rights, and Dialogical Interpretation, in: Comparative Constitutionalism IN SOUTH Asia 45 (Khilnani/Raghavan/Thiruvengadam, eds., 2013), Introduction, 11. 
in formulation of constitutional texts, read merely as exercises in miming available Euro American constitutional models!" 126 Sieder and her colleagues calls for lawyers and political scientists to pay attention to patterns of Latin American judicial interventions in specific socio-economic and cultural contexts. ${ }^{127}$ Visible in these studies is a far-reaching critique of many of the inherited assumptions regarding the purpose and scope of comparative constitutional law.

Whilst understanding the assumptions and limitations of a Western centric RoL is important, the concept should not be dismissed altogether. Taking 'thick' perspectives to the RoL provides valuable signifiers on how the term can be utilised across borders. Much has been written on the meaning of a thick RoL. For our purposes two elements are essential.

First, the unbounded sovereign nature of the concept so succinctly described in its applicability beyond 'the Law of Nations'128 to include the global inter-connectivity of relations in modern times. ${ }^{129}$ The global transference of the concept is an evolving and already well-established field of legal and development narrative. 'International' references and commitments to the rule of law are increasing. ${ }^{130}$ The concept is rapidly extending into the domain of global finance and politics. The very formulation of these types of cross-disciplinary 'soft' law declarations, arguably demonstrates recognition of the inability of states and positivist international law to cope with today's transnational socio-economic problems on their own. For example, by incorporating the RoL into the 2015 Sustainable Development Goals which unlike their previous avatar of the Millennium Development Goals, expressly includes private actors as responsible for its poverty reduction and RoL project, the concept has taken on a 'transnational' scope. It calls for the dynamic engagement of all states, international organisations and all persons and entities, public and private in a Kantian spirit of collective action.

Second, we draw on thick or substantive understandings of the RoL as requiring an appraisal or testing of the morality' 131 of laws and rights ${ }^{132}$ to ensure their legitimacy. This approach automatically legitimises human rights as fundamental rights. Bingham

\footnotetext{
${ }^{126}$ Baxi, Modelling, 29.

127 Compare here Ran Hirschl, The Judicialization of Politics, in: The Oxford Handbook of Law and Politics 119 (Caldeira/Kelemen/Whittington, eds., 2008). See also the contributions to Rachel Sieder/Line Schjolden/Alan Angell (ed.^eds.), The Judicialization of Politics in Latin America (2005). A fascinating study on the interpretive-political space opened up by the judicialization of politics is offered by Philip Liste, Transnational Human Rights Litigation and Territorialized Knowledge: Kiobel and the 'Politics of Space', 5 Transnational Legal Theory 1 (2014).

128 T Bingham, The Rule of Law (Penguin 2010) 117.

129 Ibid. Referring to the reducing power of the state. This itself implies that problems can no longer be effectively regulated on a national basis necessitating an inter-connected and plural approach to legal relations in modern times.

${ }^{130}$ McCorquodale R, 'Defining the international rule of law: Defying gravity? ' (2016) 65 ICLQ 277 for a thorough record of international statements relating to the rule of law.

${ }^{131}$ Fuller L, The Morality of Law (Yale UP 1969).

132 Dworkin R, A Matter of Principle (Harvard UP 1985) 11-12.
} 
tells us that these fundamental rights would include Magna Carta rights as they are 'the rule of law in embryo ${ }^{133^{\prime}}$ ) and international human rights. ${ }^{134}$ Furthermore, a thick RoL might also stretch beyond formality to look at the law in a historic, social and economic context. Indeed, this is in line with modern development based narratives. The 2015 Sustainable Development Agenda states how advancing the RoL requires recognition of the remnants of colonial domination on human development and economic growth, for example. ${ }^{135}$ The later point echoes Rawlsian ${ }^{136}$ ideas of economic redistribution to correct economic inequalities and advancing justice. This 'thick' RoL would therefore require paying careful attention on a case by case basis to groups of individuals who suffer historical or persistent prejudice. It would also require a discussion on how existing legal, political and economic structures, even so called liberal minority rights mechanisms, might 'brake' application of a thick RoL. TCL requires that we engage with these structures, expose their limitations and perhaps think about new methods and processes in which communities might directly advance a substantive RoL within fast emerging spaces of global tension and resistance.

Drawing on this international, thick and historically reflective understanding of the RoL helps to shape a transnational constitutional methodology for global application. The following study applies this methodology to examine some limitations and possibilities in the factual context of indigenous people.

\section{Transnational Constitutional Law and Indigenous Land Rights: A Case Study}

This section examines the increasing social displacement of Indigenous persons from their ancestral land in diverse social and historical contexts. The aim is to highlight the growing spaces of Indigenous struggle against development based encroachment on land. It explores what effects this encounter has for communities in terms of substantive equality in the form of access to justice, availability of rights and compensation. Moreover, an attempt is made to identify how traditional constitutional principles might be applied in these new global frontiers to promote the inclusion and rights of communities.

Using a 'macro' and 'micro' lens it explores how Indigenous struggles speak to the RoL through a macro examination of the 'unconstitutional' effects on Indigenous groups when

\footnotetext{
133 T Bingham, The Rule of Law (Penguin 2010) 12-13.

134 Ibid.

135 Resolution adopted by the General Assembly on 25 September 2015, Transforming our World: the 2030 Agenda for Sustainable Development, A/RES/70/1 [35].

${ }^{136}$ J Rawls, A Theory of Justice (Belknap Press 2005) containing Rawls' influential critique of prevailing neoliberal thinking which posits modern property rights as the sole foundation for justice. He makes the case for economic redistribution.
} 
faced with familiar Western liberal narratives on freedom and the parochial conceptualisation of Indigenous identity and scope of land rights. The study examines the grassroot 'micro' struggles some land connected groups face when trying to access formal legal recognition as Indigenous under international law. It shines light on the encounter of local communities with global 'soft' law norms on land resettlement and Indigenous peoples that are implemented by financial investors. This is the case when important public policy functions like resettlement and even the factual demarcation of Indigenous status is conducted by project developers. This creates access to justice and legality gaps which might be addressed through an engagement with the context specific emerging principles of TCL discussed in this section.

\section{Access to Justice and Liberalism's Inherent Problem with 'Special' Rights for Indigenous Groups}

Indigenous people refer to people who self-identify as having special attachments to their traditional land and distinctive claims to land requiring legal protection. These claims include, inter alia, collective rights to land, distinctive way of life dependent on a deep cultural and often spiritual connection to land and rights to own, use and access their traditional land and the natural resources thereon. ${ }^{137}$ Related to this special connection is a unique type of discrimination and marginalisation experienced in ongoing processes of land dispossession resulting in vulnerability. Indigenous peoples' vulnerability fundamentally relates to their struggle for recognition of their special attachment to their traditional land,138 specific way of life and the unique type of discrimination and marginalisation experienced in ongoing processes of land dispossession.

The Human Rights Commission recognises the special relationship of Indigenous people with their land resources as requiring 'positive legal measures' 139 or special measures ${ }^{140}$ as necessary for delivering substantive equality. In real terms this has been understood to mean the removal of discriminatory provisions in national laws, constitutions and policies. ${ }^{141}$ Also required is a critical analysis of how established constitutional or

\footnotetext{
137 Report of the African Commission Working Group of Experts on Indigenous Populations/Communities (2005) 89.

138 B Kingsbury, 'Indigenous Peoples' Max Planck Encyclopaedia of Public International Law. S Wiessner, 'The Cultural Rights of Indigenous Peoples: Achievement and Continuing Challenges' (2011) 22 (1) EJIL $121,127$.

${ }^{139}$ Human Rights Committee, General Comment No. 23: The rights of minorities (Art 27): 04/08/1994 CCPR/C/21/Rev. 1/Add.5, General Comment No. 23 at para 7.

140 Saramaka v Suriname Judgement of November 28, 2007 (Inter-Am. Ct. H. R. (Ser. C) no. 172) (2007)) at 85 in which the court noted how 'this Court has previously held, based on Article 1(1) of the Convention, that members of Indigenous and tribal communities require special measures that guarantee the full exercise of their rights, particularly with regards to their enjoyment of property rights, in order to safeguard their physical and cultural survival'.

141 Committee on Economic, Social and Cultural Rights, General Comment No. 20, Non-Discrimination in Economic, Social and Cultural Rights (art. 2, para. 2) U.N. Doc. E/C.12/GC/20 (2009), para 8(b).
} 
statutory rights provisions might be shaped and interpreted through economic and political assumptions on Indigenous people and their land rights. ${ }^{142}$

Lawyers working in the field of Indigenous and minority rights remark on the problems they encounter when liberal visions of equality and liberty based on individual freedom and societal stability clash with suspicion of 'different' groups and collective rights claims. ${ }^{143}$ For example, legal evidence of political resistance against difference carries through into the very different implications in international law of classification as either minority or Indigenous. ${ }^{144}$ The UN observes that the underlying assumption behind minority rights are that minorities will eventually assimilate into national life and legal formulation of minority rights shapes rights as those of individuals to preserve ${ }^{145}$ and develop their separate group identity within the process of integration into wider societal order. $^{146}$ In contrast, the underlying assumption for Indigenous people is that their predominantly Indigenous identity and unique relationship to land means they participate less in the common domain. They are essentially different, theoretically able to make a case for territorial separateness and self-determination as a distinct 'peoples' potentially holding self-determination rights: a position which appears inherently antiliberal and anti-democratic.

This legal tension echoes a deeper theoretical problem within liberalism emanating from the European post war climate. Following Nazi oppression of minority groups, principles of equality, non-discrimination and the universal 'sameness' of all human beings attempted to level the playing field and prevent future oppressive group action. ${ }^{147}$ The post war belief was that international peace was bound to a creation of common memories, common language and common dwelling. ${ }^{148}$ The universality of human rights and the hallowed idea that each person matters equally lay at the heart of all plausible (modern) political theories, ${ }^{149}$ Universal human rights offered a legal mechanism for imprinting European cohesion. In this political context, legal attempts to justify the grant of 'special' rights within statute or constitution to certain groups becomes challenging. Put another way, deeply entrenched in liberal legal frameworks is the primary

\footnotetext{
${ }^{142}$ For example, commentators argue that IPs diminished legal rights and status derives from the doctrine of discovery, which retains valuable currency in international legal discourse today Williams R.A, 'Columbus's legacy: law as an instrument of racial discrimination against Indigenous peoples' rights of selfdetermination', 8 Ariz. J. Int'l \& Comp. L. 51 (1991) 54.

143 Interview with Lucy Claridge, Head of Law, Minority Rights Group, on file with K Bhatt.

144 Working paper on the relationship and distinction between the rights of persons belonging to minorities and those of Indigenous peoples, UN Doc E/CN.4/Sub.2/2000/10, 19 July 2000 [43].

145 Pogany I, 'Minority Rights and the Roma of Central and Eastern Europe' Human Rights Law Review, 2006, Vol. 6, No.1 13.

${ }^{146}$ Working paper on the relationship and distinction between the rights of persons belonging to minorities and those of Indigenous peoples, UN Doc E/CN.4/Sub.2/2000/10, 19 July 2000 [23].

${ }^{147}$ JE Oestreich JE, 'Liberal Theory and Minority Group Rights' (1999) 21 Human Rights Quarterly 116.

148 For a succinct history of liberal views on national minorities see W Kymlicka, Multicultural Citizenship: A Liberal Theory of Minority Rights (OUP 1995) ch 3.

${ }^{149}$ Kymlicka W, Multicultural Citizenship: A Liberal Theory of Minority Rights (OUP 1995) 5.
} 
importance of the individual. For Indigenous people, this works to 'trump' the power of groups and points to a hidden bias towards a majority that makes the rules. ${ }^{150}$

International development policy methods for Indigenous peoples also embed liberal ideas on sameness on a global scale. For example, there is an emerging trend, discussed later, that seeks to dilute the 'Indigenous' legal label to one of 'vulnerable'. Other policies aim at giving consultation rights to all communities affected by development projects, not just land-connected groups. ${ }^{151}$ The vision behind both policy tools is to embrace principle of universality and sameness albeit through oppositional policy methods of dilution of identity label or elevation of consultation standard.

The problem with these approaches are that they essentially 'erase' the different and plural worldview that Indigenous groups have and the social value of those relations. Looking back to our opening definition of 'Indigenous' we see the inherent dilemma. If the special relationship to land is the essential condition of Indigenous peoples, removing it for any reason is fundamentally discriminatory and continues the structural marginalisation and vulnerability of groups. Therein lies the essential conflict of liberalism and individuality as its speaks with groups rights in the context of special rights for Indigenous people.

The fundamental misunderstanding is this. To the extent Indigenous people desire special treatment, it is in the form of recognition that they have a unique relationship to land, that it has been the subject of historic discrimination and that their traditional land rights are equal to conventional Lockean forms of individual property. Given the growing encounters of states and developers it might be more helpful to view Indigenous claims first and foremost, as fundamental rights to freedom, exercised individually or collectively, not to be discriminated against due to special land connection and freedom to choose societal integration should groups choose. This is far more factually accurate than problematic arguments primarily connected with 'speciality'. Moreover, from a TCL perspective, such a rights' based approach has the potential to open a space in which familiar constitutional principles like freedom and participation might be 'stretched' and applied within global spaces for enhanced bargaining and compromise between Indigenous People and public/private entities.

\section{The Exclusion of Indigenous Legal Status Beyond 'Blue-Water'}

This section explores the working of what Povinelli calls the 'governance of the prior'152in Western legal concepts. Here we take Povinell's notion and apply it to the issue of Indigenous legal identity to analyse how the paradigm takes shape in several global

150 JE Oestreich JE, 'Liberal Theory and Minority Group Rights' (1999) 21 Human Rights Quarterly 116.

151 Interview with Senior Land Policy Lead at a national development aid institution, on record with K. Bhatt.

152 Povinelli E, 'The Governance of the Prior' (2011) 13 Interventions 13. 
contexts. We might then draw conclusions on how to reframe issues of Indigenous identity to provide more equitable and globally relevant outcomes for groups claiming Indigenous status.

In a 2000 Working Paper, the Economic and Social Council 153 identified that that current international definition of Indigenous is modelled on the 'blue or salt water doctrine'. The legal definition recognises only one type of 'transnational' historical context. That context assumes that Indigenous people are those people beyond Europe who lived in the territory before European colonization and settlement. The 'salt water' analogy requires the act of crossing 'salt water', encounter with European colonisation and prior occupation i.e. before European arrival.

The requirement for prior occupation echoes and appears to 'stretch' Povinelli's 'prior governance' paradigm into the specifics of Indigenous identity and consequently access to rights. In Canada, Aboriginal identity and legal status have long been tied to proof of first or 'prior' occupation. The legal foundation of native title is based on the finding of a moment of pre-sovereignty historic land occupation. The position is summarised in Calder v. Attorney-General of British Columbia: 154 'the fact is that when the settlers came, the Indians were there, organized in societies and occupying the land as their forefathers had done for centuries'.

The leading case of $R v$ Van der Peet ${ }^{155}$ legally recognised Aboriginal rights as being those Aboriginal rights which existed immediately prior to contact with Europeans. Aboriginal rights possess 'original' rights because Aboriginal people are 'Aboriginal156', thus capturing the essence of being Aboriginal and the rights flowing from that status only within a framework of historical originality. We are reminded that 'this is what Indian title means ${ }^{157}$ ' Although judicial contestation exists (dissenting Justice McLachlin arguing against the parochiality of the tests stating 'A practice, however, need not be traceable to pre-contact times for it to qualify as a constitutional right. Aboriginal rights do not find

153 UN Sub-Commission on the Promotion and Protection of Human Rights, Prevention of discrimination against and the protection of minorities: Working paper on the relationship and distinction between the rights of persons belonging to minorities and those of Indigenous peoples, 19 July 2000, E/CN.4/Sub.2/2000/10, note 4 on how the blue/salt water concept hold that that Indigenous people consist of those beyond Europe who lived in a territory before European colonization and settlement and who now form a non-dominant and culturally separate group in the territories settled primarily by Europeans and their descendants. It is profoundly relational to European settlement.

154 [1973] SCR 313328.

155 R Van der Peet [1996] 2 SCR 507.

156 Noting that Aboriginal rights arise from the fact that Aboriginal people are Aboriginal and that, as academic commentators have noted, Aboriginal rights 'inhere in the very meaning of Aboriginality' $R v$ Van der Peet [1996] 2 SCR 50719.

157 Ibid 30 where Lamer CJ wrote for the majority, that 'the doctrine of Aboriginal rights (one aspect of which is 'Aboriginal title') arises from 'one simple fact: when Europeans arrived in North America, Aboriginal peoples were already here, living in communities on the land, and participating in distinctive cultures, as they had done for centuries' (emphasis in original)'. 
their source in a magic moment of European contact ${ }^{158^{\prime}}$ ), the legal characterisation of Indigenous status as 'from long ago' or since 'time immemorial' continues to have limiting consequences for Indigenous peoples and protection of their distinctive land related way of life.

Acute examples are seen in comparative geographical contexts. Common to each is the shared experience of land expulsion in each specific location and the associated struggle for legal recognition as 'Indigenous'.

In his anthropological studies on Mongolia, David Sneath notes that Mongolia has no history of European colonisation with its land systems. From the $16^{\text {th }}$ until the $20^{\text {th }}$ century Mongolia land use was primarily organised around a feudal system, which continued until socialist attempts at land collectivisation in the 1940s in which the pastoral sector was organised around centralised collective farms and state farms each managing a pastoral rural district or sum ${ }^{159}$. The inability to 'square' Indigenous status in the Mongolian context with Western 'blue water' doctrines is seen sharply. The later only recognise one type of transnational historical context in which Indigenous people are those people beyond Europe who lived in the territory first and before European settlement and therefore provides a structural legal barrier of application in Mongolia. This embedded structural bias becomes deeply problematic for land connected groups in Mongolia like the pastoralist herders discussed later, who claim Indigenous status but are not afforded legal recognition of the same in their struggle against the development of the Oyu Tolgoi mine on ancestral land.

Based on a study of communities in China, India, Bangladesh and Myanmar, Kingsbury 160 addresses the exclusionary effects of extending a definition bound in the logic of 'prior occupation' across borders. His suggestion is for facts such as prior occupation are only used as legal 'signifiers' or 'indicators' and not formal positivist requirements. Kingsbury calls for a modern reconceptualization of the definition to recognise land connected communities in those countries that have either staved off Western colonialism or rid themselves of its most direct effects in their struggle for independence. The result being that these countries see efforts to impose the European 'saltwater' concept of Indigenous in the region as a form of neo-colonialism.

The Chagos Islanders case also raises serious issues of Indigenous identity. Eminent legal and anthropological practitioners support the Indigenous status of the Chagos Islanders. Minority Rights Group International notes that 'based on its 40 years of working with Indigenous communities worldwide, the Chagossians do indeed constitute an Indigenous

\footnotetext{
158 Ibid.

159 Sneath D, 'Land Use, the Environment and Development in Post-Socialist Mongolia' (2003) 31 Oxford Development Studies 441.

160 Kingsbury B, 'Indigenous Peoples' in International Law: A Constructivist Approach to the Asian Controversy' (1998) 92 AJIL 414.
} 
people'. ${ }^{161}$ Supporting anthropological studies demonstrate that during 200 years of permanent settlement Chagossians have developed a unique range of culture pointing to specific historical cultural characteristics such as their Sega music, song, language and accents all of which are separate from other Creole cultures. ${ }^{162}$ Yet, in its 2012 ruling, the European Court of Human Rights failed to pay adequate attention to the rights of the Chagossians as an Indigenous group. ${ }^{163}$ Denial of Indigenous status has often turned upon the fact that Chagossians are not a society that European powers had crossed over 'salt water' to encounter, settle and conquer. They are not a 'pre-invasion' society of 'first inhabitants' who assert historical precedence and consequently have 'encountered' mass European colonisation. A factual block to a legal claim in Indigenous status is, therefore, the specific Chagossian history of descent from enslaved labourers from Africa and later, indentured labourers from the Indian sub-continent. ${ }^{164}$ Such a repressive position denies the unique connection to the islands with over 200 years of ancestral and cultural linkages and Chagossian self-identification as indigenous.

In Africa, fulfilling prior governance requirements is as the African Commission notes, difficult and not very constructive. 165 'Governance of the prior' paradigms concerned with evidence of factually prior occupation and encounter with white settlers become largely meaningless in plural social and historical contexts leaving a substantive lacuna in legal protection. Limiting the term Indigenous to those local peoples still subject to the political domination of the descendants of colonial settlers makes it very difficult to employ the concept in Africa. ${ }^{166}$ For example, white settlers and colonialists have not exclusively practised domination and colonisation. Dominant groups have also repressed marginalized groups since independence, and it is this sort of present day internal repression within African states that the contemporary African Indigenous movement seeks to address and by default, legal definitions of 'Indigenous' have the potential to exclude. The African Commission concludes that those applying the term Indigenous in Africa do so to address their specific human rights situation that cuts across various socio-economic systems to embrace hunter-gatherers, pastoralists and small-scale farmers: 167 the many diverse groups of pastoralists and hunter-gatherers like the Ogiek of Kenya and Hadzabe of Tanzania that identify with the Indigenous movement because of their distinctive land connection and have struggled for recognition of their basic human rights.

${ }^{161}$ Submission from Minority Rights Group International, Select Committee on Foreign Affairs dated 6 July 2008, para 37.

162Jeffery L, Chagos Islanders in Mauritius and the UK forced displacement and Onward Migration (Manchester UP 2011)for a detailed anthropological account of Chagossian culture as it differentiates from other Kreole cultures.

163 Chagos Islanders v United Kingdom [2012] No. 35622/04, ECHR 2012.

164 Jeffery supra 162 at 19.

165 Report of the African Commission's Working Group of Experts on Indigenous Populations/Communities (2005) 92.

166 Ibid.

167 African Commission on Human and Peoples' Rights, 'Indigenous Peoples in Africa: The Forgotten Peoples?' (2006) p 10. 
Each above empirical example has shed light on the structural bias and illiberal outcome of the Western construct of 'Indigenous' when placed in different social and historical contexts. What we can see is reproduction of a Western governance paradigm in plural social contexts with deeply exclusionary effects for groups claiming Indigenous status. Based on the above globally diverse scenarios conclusions can be drawn on the effects of a governance policy bounded in a European geography and a Western concern with the prior. The effect of this paradigm is one of potentially global legal expulsion in which groups are unable to access the canon of international law on Indigenous rights due to the implicit legal association of Indigenous status bounded to a specific European experience of original and prior Aboriginality and a fact pattern of settler colonialism. A TCL approach raises the constitutional concerns of this policy for legal recognition and access to justice.

\section{Rights to Land: Inequitable Constitutional Interpretation}

By and by, international courts and treaty bodies have started to fashion a concept of Indigenous land rights that gives legal recognition to the important connection between land access and human rights to property, food, water ${ }^{168}$ and culture. African and Latin American courts ${ }^{169}$ have successfully protected traditional communal and cultural rights to land and property as 'property rights'. These types of cases provide legal affirmation of the special land connected nature of Indigenous identity.

However, these purposive cases from the Global South, are not indicative of other domestic legal trends. In Canada and Australia, the legal burden ${ }^{170}$ for proving existence of traditional rights to land rests on Aboriginal people even though they are often the least equipped in terms of financial assistance and technical knowledge of the relevant common law system. So, specific legal tests exist for proving Aboriginal rights. In Canada, traditional rights are granted legal legitimacy only if they are based on 'practices, customs and traditions that are rooted in the pre-contact societies'. ${ }^{171}$ High barriers to legal protection require groups to prove that rights be 'integral to the distinctive culture' of the

\footnotetext{
168 Yakye Axa Indigenous Community v Paraguay [2005] Judgement of 17 June 2005 (Inter-Am Ct. H. R. (Ser. C) no. 124 (2005)) at 167 stating 'for Indigenous groups access to their ancestral lands and to the use and enjoyment of the natural resources found on them is closely linked to obtaining food and access to clean water'.

169 There has been a wave of recognition from the Latin American and African Courts, reading rights to property to include communal forms of Indigenous property: Mayanga (Sumo) Awas Tingi Community $v$ Nicaragua [2001], Yakye Axa Indigenous Community v Paraguay [2005]; Sawhoyamaxa Indigenous Community v Paraguay [2006] and Saramaka People v Suriname [2007]; 276/03 Centre for Minority Rights Development (Kenya) and Minority Rights Group International on behalf of Endorois Welfare Council v. Kenya, African Commission on Humans and Peoples' Rights, 46th Ordinary Session, 25 November 2009.

${ }^{170}$ See Delgamuukw v British Colombia [1997] 3 SCR Lamer CJ stated that 'In order to establish a claim to Aboriginal title, the Aboriginal group asserting the claim must establish that it occupied the lands in question at the time at which the Crown asserted sovereignty over the land subject to the title' 144.

171 See $R v$ Van der Peet [1996] 2 SCR 50762.
} 
group. ${ }^{172}$ In Australia, there is a similarly onerous legal requirement that the laws and customs have 'continued substantially uninterrupted by each generation since sovereignty'. ${ }^{173}$ In this brief case analysis, we find evidence that the requirements and burden of Western liberal legal protection are so high that many groups are simply unable to obtain recognition of the relationship they continue to have with their traditional land: an unjust position that is not lost on domestic law reform commissions. ${ }^{174}$

Regressive constitutional interpretation of rights is also found when groups try to gain legal protection for the transformation of traditional rights into a modern equivalent that meets their social, economic and cultural development needs. In Canada, the Supreme Court has thrice denied constitutional protection of fishing and harvesting rights traditionally used for socio-economic and cultural purposes when groups have attempted to develop those rights for commercial trading purposes to create sustainable livelihoods and food security ${ }^{175}$. Again, we see echoes of Povinelli's governance of the prior in legal justification for denial of ameliorated rights. Justifications revolve around the protection of the historic cultural right and the prevention of a 'prior' traditional claim that might gain priority over non-Aboriginal commercial or sports fishers'. Such judicial positions appear to stifle the development of land rights even within evolved and sophisticated liberal constitutional frameworks.

\section{Non-State Actors and Informal Norms: Financial Investors and Free, Prior and Informed Consent}

Regulation of public policy issues like land and Indigenous rights increasingly occurs through the informal policy norms of private investors. This section highlights two remarkable patterns of cross border Indigenous governance involving financial investors: factual identity demarcation and the transnational process of 'free, prior and informed consent'. The section also considers how these informal norms might illustrate and develop TCL.

Specific norms regulating land eviction and the land rights of Indigenous people are increasingly designed and applied in the context of large scale development projects

172 Generally following the approach in $R v$ Sparrow [1990] 1 S.C.R. 1075 in which the Musqueaum right to fish for food was based upon anthropological evidence that salmon fishery has always constituted an integral part of their distinctive culture.

${ }^{173}$ See Members of the Yorta Yorta Aboriginal Community v Victoria (2002) 214 CLR 422; Risk v Northern Territory of Australia [2006] FCA 404 at 97(c) per Mansfield J; supported on appeal in Risk $v$ Northern Territory [2007] 240 ALR 75 at 78-79.

${ }^{174}$ Australian Law Reform Commission, Issue Paper 'Substantial Interruption', para 179-180 in Review of the Native Title Act 1993 (IP 45), 2014 noting the possibility of an inequitable interpretation of the substantial interruption test and thus considering methods of reform for the test including 'the empowerment of courts to disregard substantial interruption...where it is in the interests of justice to do so'.<www.alrc.gov.au/publications/issues-paper/\%E2\%80\%98substantial-interruption $\%$ E2\%80\%99-

0\#_ftn226>.

${ }^{175} R$ v Van der Peet [1996] 2 SCR 507; In R v NTC Smokehouse [1996] 2 SCR 672; Lax Kw'alaams Indian Band v Canada [2011] 3 SCR 535. 
requiring the relocation of communities by private investors. These projects are financed through financial organisations. Examples include the 2012 International Financial Corporation's (IFC) and the 2014 European Bank of Reconstruction and Development's (EBRD) risk management safeguard policy 5 on land and involuntary resettlement policy and safeguard policy 7 on Indigenous peoples. Use of these types of policies has been long known, advised on and assisted by practitioners' active in advising clients in cross-border transactions.

It will be of concern to public and private lawyers that the factual demarcation of 'who' is Indigenous is, as we will see, increasingly being decided directly by financial organisations. Performance Standard 7 makes Indigenous determination a matter for the IFC or EBRD's private client who may seek input from competent professionals ${ }^{176}$. The World Bank, IFC and EBRD recognise that there is no universally accepted definition of Indigenous peoples ${ }^{177}$ and take this legal ambiguity to present their own definitions. Common to the IFC 178 and EBRD ${ }^{179}$ is the use of the term in a generic sense to refer to a distinct social and cultural group possessing the following characteristics in varying degrees including self-identification, collective attachment to geographically distinct habitats and distinct language. The EBRD also classifies as Indigenous, people with descent from populations who have traditionally pursued non-wage (and often nomadic/transhumant ${ }^{180}$ ) subsistence strategies and whose status was regulated by their own customs or traditions.

Studies on Indigenous rights in the context of World Bank policy conclude that in states where Indigenous groups are politically organised and familiar with World Bank policy, international organisations are almost inevitably drawn into processes of social group self-identification and definition. ${ }^{181}$

A case in point is that of the Oyu Tolgoi mining project in Mongolia discussed above. Performance standards 5 on involuntary resettlement were triggered by both the IFC and EBRD. Notwithstanding the EBRD's express policy position classifying as Indigenous, people with descent from populations who have traditionally pursued non-wage (and often nomadic/transhumant) subsistence strategies, the internal decision was made not to apply the performance requirement 7 on Indigenous people. This conflict meant that

176 IFC Performance Standard 7, para 8 stating that the client will identify, through an environmental and social risks and impacts assessment process, all communities of Indigenous Peoples within the project area of influence who may be affected by the project, as well as the nature and degree of the expected direct and indirect economic, social, cultural.

177 Reference is made to World Bank webinar involving K. Bhatt and senior World Bank management, details of which are on file with the author.

178 IFC Performance Standard 7, para 5.

179 EBRD Performance Requirements 7, para 3.

180 Ibid para 4.

${ }^{181}$ See I Brownlie GS Goodwin-Gill \& S Talmon, The Reality of International Law: Essays in Honour of Ian Brownlie (Clarendon 1999) 328; B Kingsbury, 'Indigenous Peoples' in International Law: A Constructivist Approach to the Asian Controversy' (1998) 92 AJIL 414. 
financial institutions were, through grievance complaints lodged by herder households, ${ }^{182}$ brought directly into discussions on the herders' claim of Indigenous status and special connection to land, which investors, with state backing, continue to resist.

In another study of World Bank practices in Morocco, Sarfaty finds that bank managers decided not to recognise Berbers as Indigenous notwithstanding self-identification. The reason for this was an alignment of policy practice with the state's non-recognition of ethnic minorities within their borders as Indigenous ${ }^{183}$. Similarly, in other development projects, international organisations have justified the non-application of Indigenous policy based on lack of national recognition notwithstanding factual claims made by local communities in Africa and India claiming Indigenous status. ${ }^{184}$

What TCL scholars might deduce from these examples is a developing bank of precedents in which private investors have carved a policy space in which to make decisions on factual identity demarcation. In many cases land connected communities are already subject to legal recognition blocks at the state level, as discussed above. Financialization and globalisation processes through which now private investors also have a say in identity have the potential to further compound access to justice for land connected groups The EBRD's potential future investments within Middle Eastern countries such as Jordan ${ }^{185}$ which have, like Morocco, communities self-identifying as nomadic and into which future investments are planned, will potentially provide further examples of investor determination. This pattern of what we might call 'investor-state sovereignty' over factual Indigenous demarcation constitutes major transnational constitutional law dilemmas for Indigenous struggles directly born out of growing financialization and globalisation, that we believe the academy must engage with.

Broadly speaking, the objective of private investor resettlement policy is to actively incorporate affected communities into projects, make positive contributions to development ${ }^{186}$ or, at a minimum, to do no harm to local communities. The policy of the

182 CAO Assessment Report, Second Complaint (Oyu Tolgoi-02) Regarding the Oyu Tolgoi Project (IFC \#29007 and MIGA \#7041).

183 Sarfaty GA, 'The World Bank and the Internalization of Indigenous Rights Norms' (2005) 114 The Yale Law Journal 1791.

184 See the Bujugali hydroelectric project in Uganda, the Second Water Supply and Environmental Sanitation Project in Karnataka approved in 2001 affecting the Lambanis and Siddis, ethnic groups with distinctive cultural practices who could arguably qualify as Indigenous peoples under Bank policy and on Asia, see more broadly Kingsbury B, 'Indigenous Peoples' in International Law: A Constructivist Approach to the Asian Controversy' (1998) 92 AJIL 414.

185 See the list of new wind, waste, solar and power projects project finance by the EBRD in Jordan: available at: http://www.ebrd.com/work-with-us/project-finance/project-summarydocuments.html?1=1\&filterCountry=Jordan.

186 EBRD Performance Requirement 52014 on land and involuntary resettlement. Its objective is to mitigate adverse social and economic impacts from land acquisition and to restore, and where possible, potentially improve, their standards of living and/or livelihoods and IFC Performance Standards 2012 with a similar provision. 
EBRD emphasises the need for free, prior and informed consent (FPIC) of Indigenous people and specifically ties its content to the United Nations Declaration on the Rights of Indigenous Peoples (UNDRIP). ${ }^{187}$ According to the EBRD, the notion behind FPIC is to provide a special process whereby Indigenous people are informed about development activities in a timely manner and provided with an opportunity to approve (or reject) a project without any form of manipulation or coercion prior to the commencement of operations.

FPIC is an interesting process with potential transformative transnational constitutional benefits for local communities. Given that it's fundamental purpose is inclusion and participation it speaks across borders, state and non-state actors, financial and legal systems directly to the local struggle.

We know that the right of Indigenous people to FPIC in relation to developments on their land is a growing standard in international law with its clearest elaboration contained in articles 19 and 32(2) of UNDRIP, which celebrates its tenth anniversary this year. A study by the International Law Association found a wide range of customary international law norms concerning Indigenous peoples, including 'the right to be consulted with respect to any project that may affect them ${ }^{188}$. The later study will have drawn on the wealth of confirming case law and commentary pointing to a well-defined legal consensus that states have a minimum duty to consult ${ }^{189}$ in good faith with groups regarding any developments on their ancestral land. Application of FPIC towards private entities does however remain untested and problematic. Whilst some policy papers like that of the EBRD noted above, might say otherwise, it is broadly recognised that FPIC does not constitute a veto right ${ }^{190}$ against private investors. The legal efficacy of consultation rights vis a vis an investor remains moot. ${ }^{191}$

Nevertheless, the emergence and development of the notion of FPIC whilst still in its infancy remains vital to the development of community led tools and governance systems through which people might draw attention to the local hardships caused by increased financialization and globalisation. TCL might use these spaces to show how familiar constitutional law principles like consultation, fairness and the RoL can apply equally to (a) a citizen based in the UK using traditional judicial review mechanisms against a government over encroachment of a planned rail concession, and (b), a nomadic farmer

187 Performance Requirement 7 specifically mentions UNDRIP.

188 ILA Committee on the Rights of Indigenous Peoples, Interim Report (2010), p. 51.

${ }^{189}$ On the requirement to negotiate and consult with Indigenous groups with respect to impacts on their land, see Delgamuukw v British Colombia [1997] 3 SCR, in Saramaka People v Suriname [2007].

190 See Commission on Human Rights, Sub-Commission on the Promotion and Protection of Human Rights. Working Group on Indigenous Populations, 'Standard Setting: legal commentary on the concept of free, prior and informed consent (2005), UN Doc: E/CN.4/Sub.2/AC.4/2005/WP.1, 14 July 200547.

${ }^{191}$ In the context of balancing consultation rights with investors' rights however, the legal position is still emerging. See Grand River Enterprises Six Nations Ltd et al v United States of America, NAFTA (UNCITRAL) Award (12 January 2011) para 210 in which the tribunal engaged in obiter comments on the issue of whether such rules of customary international law exist but did not reach a specific conclusion on the issue. 
in Mongolia expelled from his ancestral land to make may for a consortium of private concessionaires through a modern articulation of FPIC.

This more dynamic examination of FPIC permits us to push the envelope beyond that of a procedural consultation right to one with truly substantive and transformative global potential. Fundamentally grounded in the rights of all people to self-determination, the concept is not only tied to independence but moves beyond the moment of decolonisation to include the right of peoples to freely choose their political and economic future within the existing boundaries of the state. ${ }^{192}$ This suggests that FPIC is far more than a 'light' standard of mere procedural consultation but when thoroughly understood strikes to the core of Indigenous claims. Conceptually, the syntax of free, prior and informed speaks directly to the experience of land connected persons in its representation of all the issues that groups suffered under both colonial, non-colonial legal systems and modern governments: coercion (not 'free'), excluded (never 'prior') and voiceless (no 'consent'), making it a valuable modern tool for enunciating Indigenous claims in the following ways. The concept is not historically limited to first occupants and the 'governance of the prior' and is detached from a pre-invasion colonial history embraces land connected groups that do not share a settler colonial history.

Thus, FPIC does not associate itself with one specific encounter in which Indigenous people experienced discrimination, typically colonialism and might as the African Commission envisages encounter discrimination based on biased development paradigms which aim at fracturing the special relationship with land by labelling the ways of life of Indigenous as 'primitive', 'anti-modernity' and even degrading to the environment. ${ }^{193}$ The concept also moves away from the exercise of defining 'who' is Indigenous by a historic backward-looking connection to land and prior occupation with its potential to result in ridiculous questions of whether groups have been oppressed enough. A FPIC approach directly articulates the distinctive core of the Indigenous movement as a fluid movement for rights and justice for those left at the margins of development, who are perceived negatively by mainstream society and whose culture and distinctive land connected way of life has been met with discrimination. ${ }^{194}$ FPIC is also alive to the practical point that people are more likely to collectively identify and form a shared historic cultural narrative when they are historically oppressed and this can happen at any point in time, as was the case with the Chagossians and regardless of 'who came first' making it a crucial emerging standard within TCL.

192 See Commission on Human Rights, Sub-Commission on the Promotion and Protection of Human Rights Working Group on Indigenous Populations, 'Standard-Setting: legal commentary on the concept of free, prior and informed consent (2005), UN Doc: E/CN.4/Sub.2/AC.4/2005/WP.1, 14 July 2005 at para 34.

193 Report of the African Commission's Working Group of Experts on Indigenous Populations/Communities (2005) 29.

194 African Commission on Human and Peoples' Rights, 'Indigenous Peoples in Africa: The Forgotten Peoples?' (2006) 11. 


\section{Conclusion and Opportunities}

This chapter has provided an overview of TCL. TCL is forged from the union of two legal fields: constitutional law and transnational law. We understand transnational law as a way of looking at law in the context of increased financialization and globalisation rather than as a distinct legal field. Examining this phenomenon and its impacts through wellknown constitutional law concepts like the RoL, equality and access to justice presents a new and robust method for crystallising the struggles and problems of the increasing number of people: the 'bottom billion', that have through processes of financialization and globalisations fallen out of, or were never made party to, the Western 'social contract'.

We see TCL emerging on two levels. On a macro level through for example settings that shine light on processes of globalisation and financialization such as trade law, international human rights adjudication concerning civil, socio-economic and cultural rights, studies of comparative constitutional law and post-colonial approaches to law. TCL also emerges on a micro level through careful ethnographic and anthropological studies examining struggles and resistance for example from eviction, within changing economic and political landscapes. Finally, our idea of a transnationally relevant RoL is an international, 'thick' and historically reflective. This helps to shape a transnational constitutional methodology for global application. The case study attempts to apply a TCL approach to matters of Indigenous identity, land rights and consultation as an example of the opportunity that we think TCL extends. 